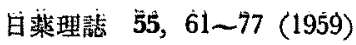

\title{
KI の鷄胎仔に及ぼす影響について
}

\author{
高橋 敬蔵 \\ (时和医科大学薬理学教空 (主任 角尾 滋教授〕) \\ （昭和 33 年 9 月 20 日受付 [特])
}

\begin{abstract}
緒
言

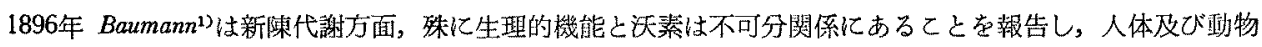

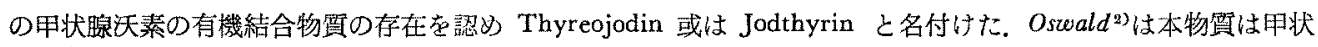

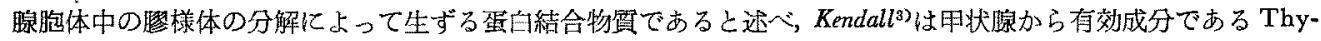
roxine を分離した，爾来沃素の甲状腺江関する脈大な研究がなされ，近年放射性沃秦の利用と共に，その研究は 長足の進歩を遂げた.

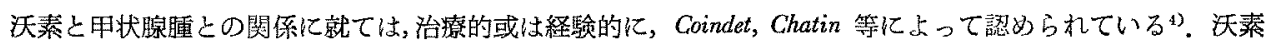
の甲状腺に対する作用に就ては，沃素の欠乏が甲状臆の機能を減退せしめると云われ，一方甲状腺機能元進叐に

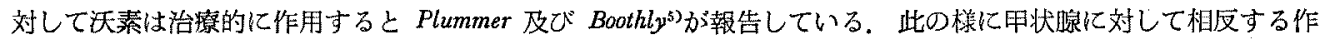
用を示す沃素の作用機転に就ては諸説があり末だ明らかでないと謂われている。

正常動物に沃素を投与した場合の甲状腚の病理組織学的研究は幾多の学者によつてなされ，所謂膠様甲状腺

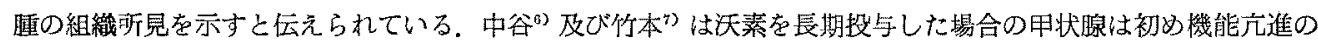

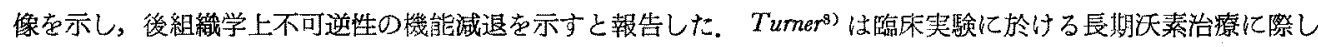

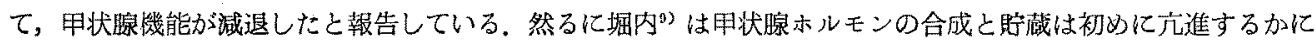

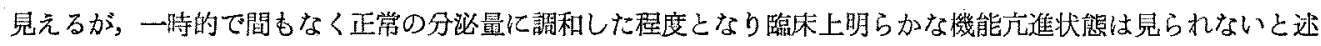
ベている.

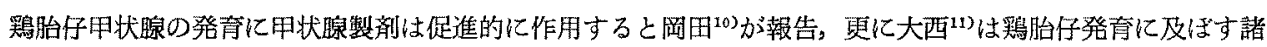

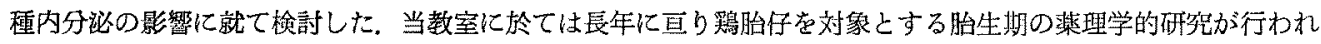

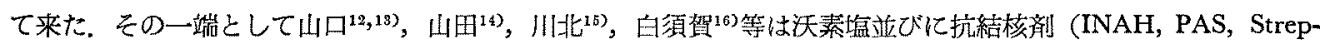

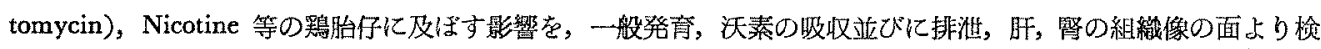

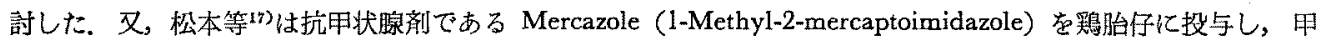
状腺腫を認め，この組織像仙投与量によって異ると報告した。

余は天化カリウ $\Delta の$ 鷄胎仔に及ばす影響を，甲状腺の組織学的梌索，胎仔の一般発青並びに甲状腺による ${ }^{131}$ 撕取の点から吟味し，更に既往の業縝と比校检討を陚みた。
\end{abstract}

\section{実験材料並びに実験方法}

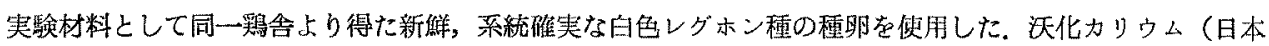
萖局方）の投与に際しては KIが瑊菌蒝溜水 $0.1 \mathrm{cc中に夫々} 50 r ， 100 r ， 500 r ， 1 \mathrm{mg} ， 5 \mathrm{mg}, 10 \mathrm{mg}$ 宛含有される

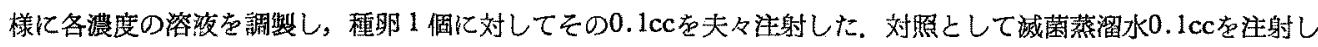
た例（以下 Aq 注射例と略記す）を用いた。種卵に対する注射法は先ず畉嵦の污物を除外し，尖端部を75\%アル コールにて清拭消毒し，その䏴々外側部に於て小孔を器ち、ッベルクリン用注射器を用いてカラザを澼け，卵白 


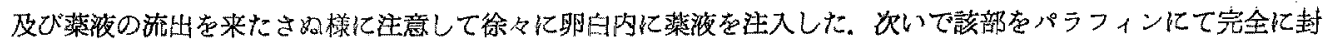

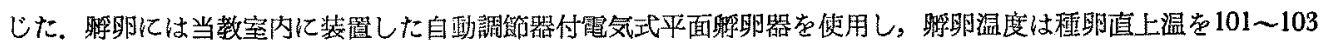

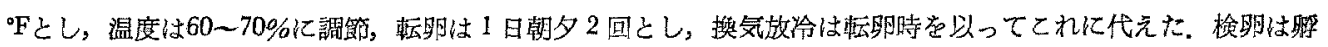

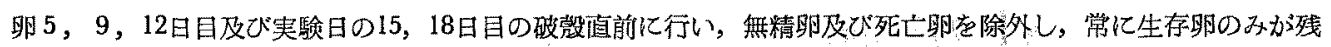

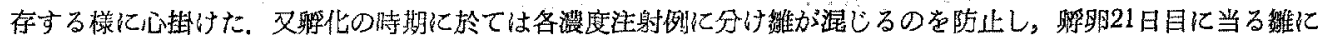
つい検蔡を行った。

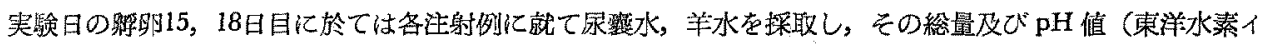

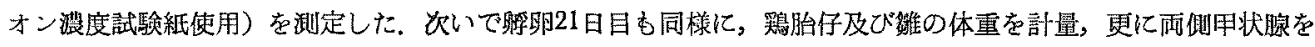

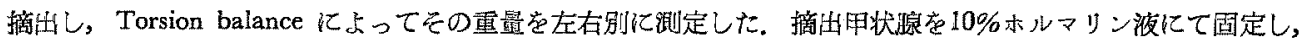
パラフィン包埋を経てへマトキシリン・エオシン雷染色標本，ワン・ギーソン染色標本を作製して検鏡した.

\section{実 験 成 綪}

\section{I 、管胎仔及び雛の肉眼的所見}

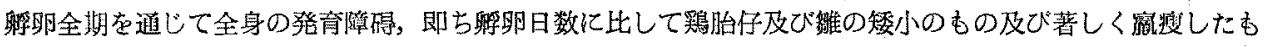

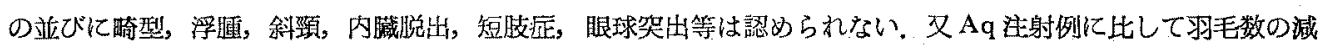

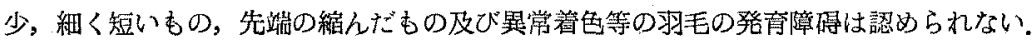

\section{I. 甲状腺の病理組織学的所見}

\section{1) 肉眼的所見}

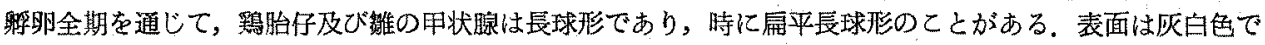
平滑光沢があり，弾力性抵抗を有している．KIの注射量の增加と伴って甲状腺は屚慢性に腫大し，結節の形成

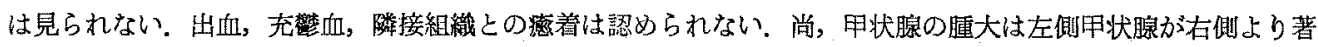
しい例が多い。

\section{2) 組織学的所見}

\section{㭌明15日目 (第 1 表参照)}

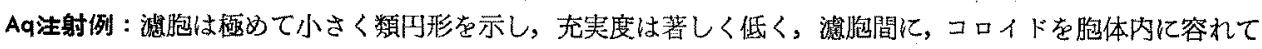
明らかな腔形成を示さない幼弱な滤胞上皮練胞と思われる大型の絊胞が浔められる。極めて少量のコロイドはエ オシンン跀染し，周辺空胞は認められない，憈胞上皮細胞は極めて小さく，骰子形をなし，一周に配列する。核 は類円形を呈しクロマチンに富む，間賀に於て，結合織は明らかでなく，血管充盈は見られない，

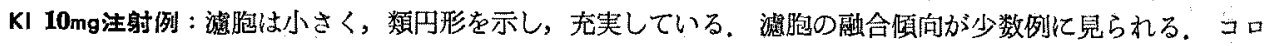

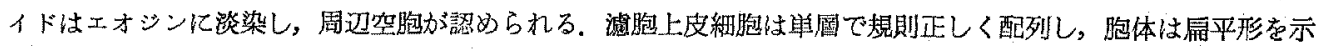

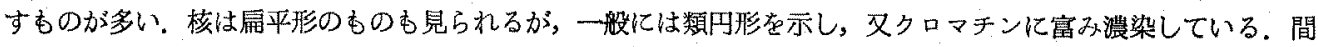

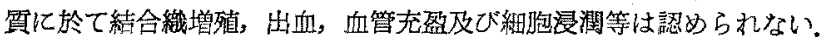

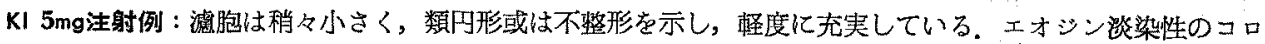

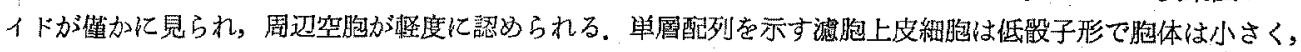

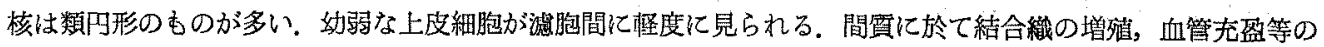
所見は認められない。

KI Img注射例：滤胞は小類円形にして，柽度の充実を示す．著明に周辺空胞を有するコロイドはエオシンに

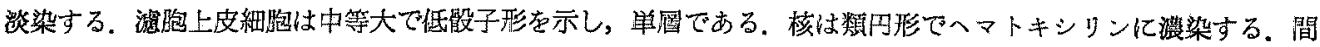

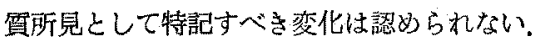

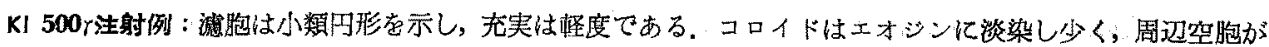

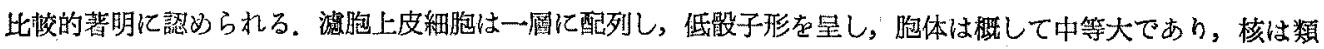

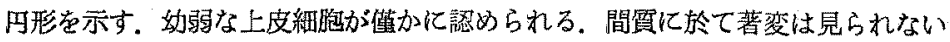




\begin{tabular}{|c|c|c|c|c|c|c|c|c|}
\hline \multirow{2}{*}{\multicolumn{2}{|c|}{ 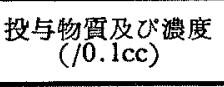 }} & \multicolumn{2}{|r|}{ 邲 } & 卵 & 15 & 日 & \multicolumn{2}{|c|}{ 目 } \\
\hline & & $\mathrm{Aq} 0.1 \mathrm{cc}$ & $\mathrm{KI} 10 \mathrm{mg}$ & $\mathrm{KI} 5 \mathrm{mg}$ & $\mathrm{KI} / \mathrm{mg}$ & KI $500 y$ & $\mathrm{KI} 100_{r}$ & KI $50 r$ \\
\hline & 形 䇛 & 類円形 & 類円形 & $\begin{array}{l}\text { 類円形 } \\
\text { 不慗形 }\end{array}$ & 類円形 & 類円形 & 類円形 & 類円形 \\
\hline & 大 中心部 & 極小 & 小 & 稍々小 & 小 & 小 & 小 & 小 \\
\hline & さ周辺部 & 極小 & 小 & 稍々小 & 小 & 小 & 小 & 小 \\
\hline \multirow[t]{3}{*}{ 胞 } & 垶 圈 & 1 周 & 1 圈 & 1 層 & 1 層 & 1 㽞 & 1 盗 & 1 凰 \\
\hline & 充実度 & - & + & \pm & \pm & \pm & \pm & \pm \\
\hline & 融合傾向 & - & $-\sim \pm$ & - & - & - & - & - \\
\hline \multirow{8}{*}{ 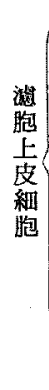 } & (形 愳 & 版子形 & $\begin{array}{l}\text { 歇子形 } \\
\text { 雇平形 }\end{array}$ & 低歇子形 & 低骰子形 & 低骰子形 & $\begin{array}{l}\text { 低股子形 } \\
\text { ～能子形 }\end{array}$ & 澱子形 \\
\hline & （大きさ & 㴍小 & 稍々小 & 小 & 小 & 小 & 稍々小 & 稍々小 \\
\hline & 原 明るさ & $\begin{array}{l}\text { 盟一稍々 } \\
\text { 暗 }\end{array}$ & 稍々暗 & 稍々暗 & 明 & 稍々暗 & 稍々境 & 暗 \\
\hline & 項 幼弱細胞 & \pm & + & + & $H$ & \pm & \pm & 一 \\
\hline & 剝 離 & - & - & - & - & - & - & - \\
\hline & 形 態 & 類円形 & $\begin{array}{l}\text { 根して } \\
\text { 類円形 }\end{array}$ & $\begin{array}{l}\text { 概して } \\
\text { 類円形 }\end{array}$ & 類円形 & 類円形 & 類円形 & 類円形 \\
\hline & 核 $\{$ 大きさ & 大 & 中 & 中 & 中 & 中 & 中 & 中 \\
\hline & 明るさ & 暗 & 暗 & 暗 & 暗 & 暗 & 暗 & 瞕 \\
\hline \multirow{3}{*}{$\begin{array}{l}コ \\
\square \\
1 \\
k\end{array}$} & (有 無 & $-\sim \pm$ & \pm & $-\sim \pm$ & + & $-\sim \pm$ & \pm & - \\
\hline & $\{$ 染色姓 & 焱染 & 淡染 & 淡染 & 淡染 & 淡染 & 淡染 & 淡染 \\
\hline & | 空胞形成 & - & + & $-\sim \pm$ & + & $\pm \sim+$ & - & - \\
\hline \multirow{3}{*}{ 䦔 } & 結合織増殖 & - & - & - & - & - & - & - \\
\hline & 䨆 血 & - & - & - & - & - & - & - \\
\hline & ，出 血 & - & - & - & - & - & - & - \\
\hline
\end{tabular}

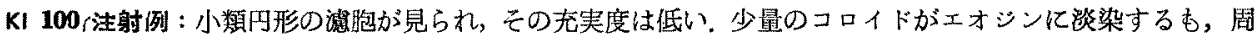

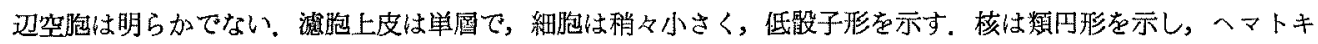

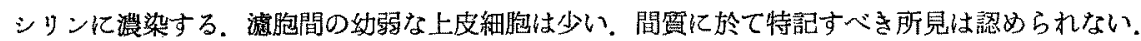

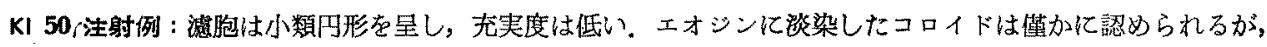

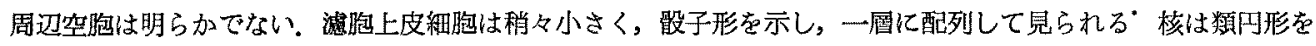
示し，クロマチンに富む． 幼弱な上皮紐胸は少い．間質に於て結合織増殖，出血，血管充盟等は認められない.

\section{盟卵18日目（第 2 表参照）}

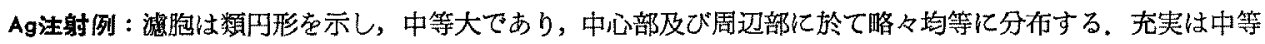

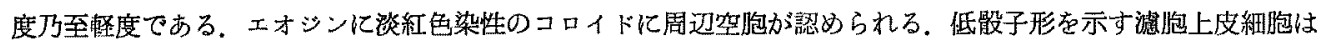

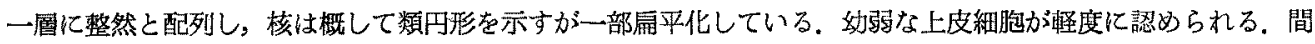
質に於ては未だ結合蟣の発育が著明でなく，出血，血管充盈等は見られない，

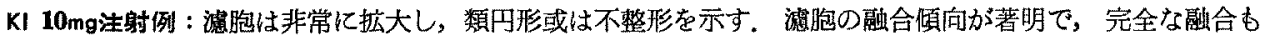

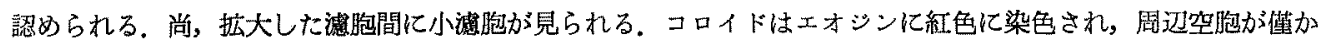
に認められる，滤胞上皮細胞は扁平形のものが非常に多く，細胞の配列の層化及び細胞の剖離は認められない。

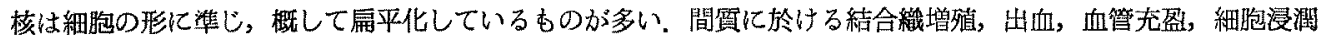
等の所見は認められない。

KI 5mg洼射例：濾胞は一般に類门形であるが，一部不整形を示す．中心部では概して中等大であるが，周辺

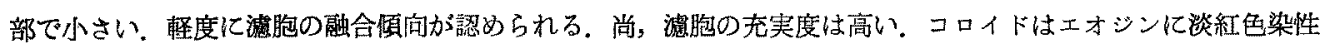

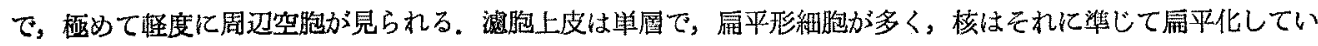




\begin{tabular}{|c|c|c|c|c|c|c|c|c|}
\hline \multirow{2}{*}{\multicolumn{2}{|c|}{ 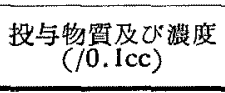 }} & \multicolumn{2}{|l|}{ 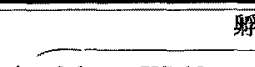 } & 卵 & \multirow{2}{*}{$\frac{18}{K I 1 \mathrm{mg}}$} & \multirow{2}{*}{ 日 } & \multicolumn{2}{|l|}{ 目 } \\
\hline & & $\mathrm{Aq} 0.1 \mathrm{cc}$ & $\mathrm{KI} 10 \mathrm{mg}$ & $\mathrm{KI} 5 \mathrm{mg}$ & & & $\mathrm{KI} 100 r$ & $\mathrm{KI} 50 \gamma$ \\
\hline & 形 態 & 類円形 & $\begin{array}{l}\text { 類円形 } \\
\text { 不整形 }\end{array}$ & $\begin{array}{l}\text { 類叮形 } \\
\text { 不整形 }\end{array}$ & 数円形 & 類円形 & 類円形 & 類円形 \\
\hline & 大 中心部 & 中 & 大一小 & 申 & 大一中 & 中 & 中 & 中 \\
\hline & さ 周辺部 & 中 & 大小 & 小 & 小 & 中 & 小 & 小 \\
\hline \multirow{5}{*}{ 胞 } & 壁 賣 & 1 層 & 1 圓 & 1 圓 & 1 層 & 1.層 & 1 圓 & 1 圈 \\
\hline & 宎実度 & $\pm \sim+$ & $\pm \sim H$ & $H$ & + & + & + & \pm \\
\hline & 融合傾向 & - & $\pm \sim+$ & \pm & $-\sim+$ & \pm & $-\sim \pm$ & $-\sim \pm$ \\
\hline & ( 形 鄎 & 低骰子形 & $\begin{array}{l}\text { 屓平形 } \\
\text { 低耶子形 }\end{array}$ & 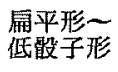 & 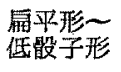 & 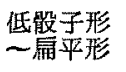 & $\begin{array}{l}\text { 低骰子形 } \\
\text { ，虛平形 }\end{array}$ & 股子形 \\
\hline & |大きさ & 中 & 中 & $\begin{array}{l}\text { 大一稍 } \\
\text { 々小 }\end{array}$ & 中 & 中 & 中 & 中一稍 \\
\hline \multirow{6}{*}{$\begin{array}{l}\text { 溜 } \\
\text { 脃 } \\
\text { 上 } \\
\text { 緗 } \\
\text { 胞 }\end{array}$} & 原 明るさ & 唃々暗 & 稍々暗 & 稍々暗 & 稍々暗 & 暗 & $\begin{array}{l}\text { 稍\&暗 } \\
\text { 〜明 }\end{array}$ & 暗 \\
\hline & 貿 幼弱細胞 & \pm & \pm & \pm & \pm & + & $-\sim \pm$ & + \\
\hline & （軳 滩 & - & - & - & - & - & - & - \\
\hline & (形 鄎 & 類円形 & 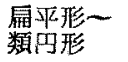 & 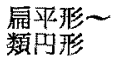 & $\begin{array}{l}\text { 類円形一 } \\
\text { 扇平形 }\end{array}$ & $\begin{array}{l}\text { 類円形〜 } \\
\text { 症苾形 }\end{array}$ & $\begin{array}{l}\text { 類円形 } \\
\text { 扇平形 }\end{array}$ & 類円形 \\
\hline & 核 大きさ & 中 & 申 & 中 & 中 & 中 & 中 & 大 \\
\hline & 明るさ & $\begin{array}{l}\text { 䊑々暗 } \\
\text { 〜暗 }\end{array}$ & 暗 & $\begin{array}{l}\text { 稍々暗 } \\
\text { ～暗 }\end{array}$ & 暗 & 暗 & 暗 & 稍々暗 \\
\hline \multirow{3}{*}{$\begin{array}{l}7 \\
\square \\
5 \\
k\end{array}$} & 有 無 & + & + & + & + & + & + & $-\sim \pm$ \\
\hline & 染色性 & 淡紅 & 紅 & 淡紅 & $\begin{array}{l}\text { 癷組一 } \\
\text { 淡染 }\end{array}$ & 淡紅 & 淡紅 & 淡紅 \\
\hline & 空胞形成 & $-\sim \pm$ & $\sim \sim \pm$ & $-\sim \pm$ & $-\sim \pm$ & - & - & - \\
\hline \multirow{3}{*}{ 間 } & 結合織增殖 & - & - & - & - & - & - & - \\
\hline & 鰹 血 & - & - & - & - & - & - & - \\
\hline & 出 血 & - & - & - & - & - & - & - \\
\hline
\end{tabular}

る。間貿には特記すべき所見が見られない，

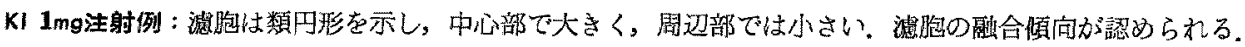
コロイトはエオシンに㷋紅色乃至淡く染色され，周辺空胞が見られる，滤胞上皮は単圆で，細胞は一般に低骰子 形であるが，扁平形細胞を混在する．核は類円形乃至扁平形を呈し，クロマチンに富んている．間筫に於ては著 变を認好ない。

KI 500 注射例：淲胞は周辺部, 中心部共に中等大で類円形を呈す。コロイドはエォシンに淡紅色に染色され

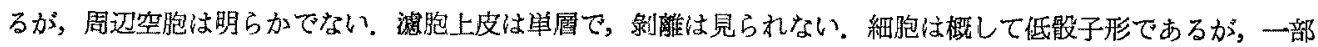
扁平形を示す，核性類円形を示すむのが多く，クロマチンに富んでいる，纤弱な上皮細胞が滤胞間に認められる。 間質に於て，結合織の增殖，出血，血管充盈等は認少られない。

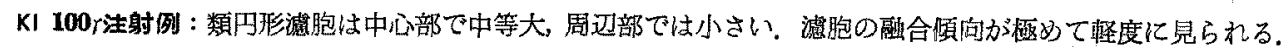
コロイドはエオシンに濙紅色染性であるが，周辺空胞は明らかでない，滤胞上皮は単周で，細胞は一般に低股子 形を示すが，屚平形のものも模かに㒛められる，核は概して類円形を示す，間賀では特記すべき所見が見られな い.

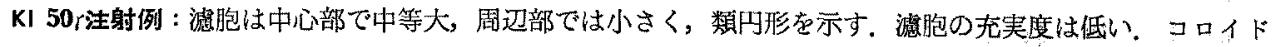

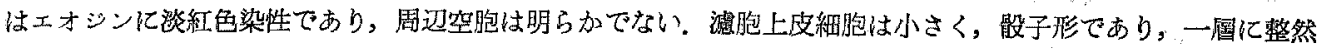
と配列する．核は類円形で稍々大さい，滤胞間に奻弱な上皮細胞が認められる，間筫に於ける結合織增殖，出血， 血管充盈等は見られない。 


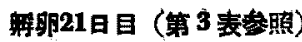

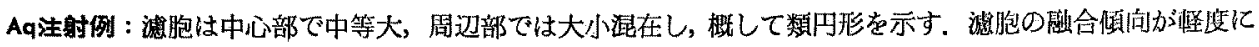

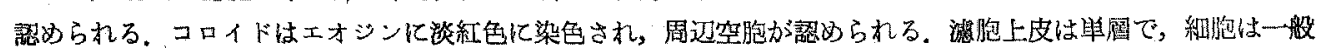

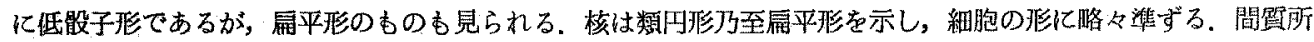

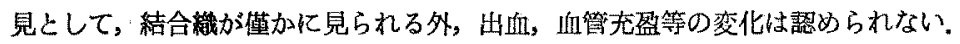

KI 10mg注射例 : 完全躬化化成功しなかった。

KI $5 \mathrm{mg}$ 注射例：浦胞は著しく拡大し，不整形を示すすのが多く，周过部では中等大の滤胞を混ずる，滤胞の

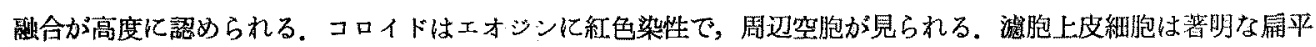

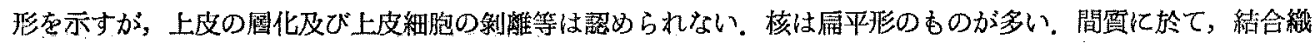
增殖，出血，血管充盈，絊咆浸洞等の所見俚見られない。

KI Img 注射例：溜胞は中等大で類円形を示し，融合攧向が著しい，コロイドはエオジンに淡縕色染性で，周

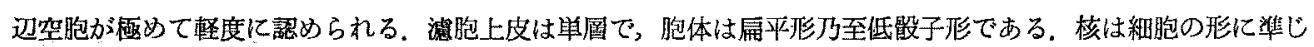

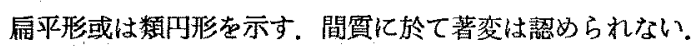

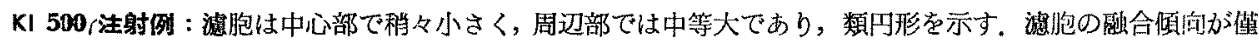

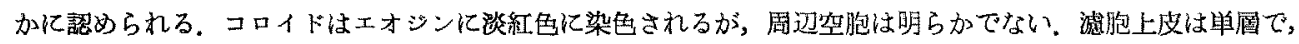

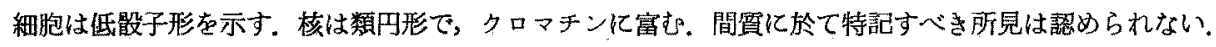

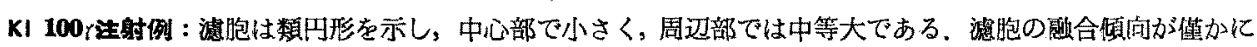
見られる。コロイドはエオジンに焱紅色染性で，周辺空胞は明らかでない，源胞上皮細胞は低股子形を示し，上 皮の層化は見られない，核は類円形である，間䁈に於ける著変は認められない．

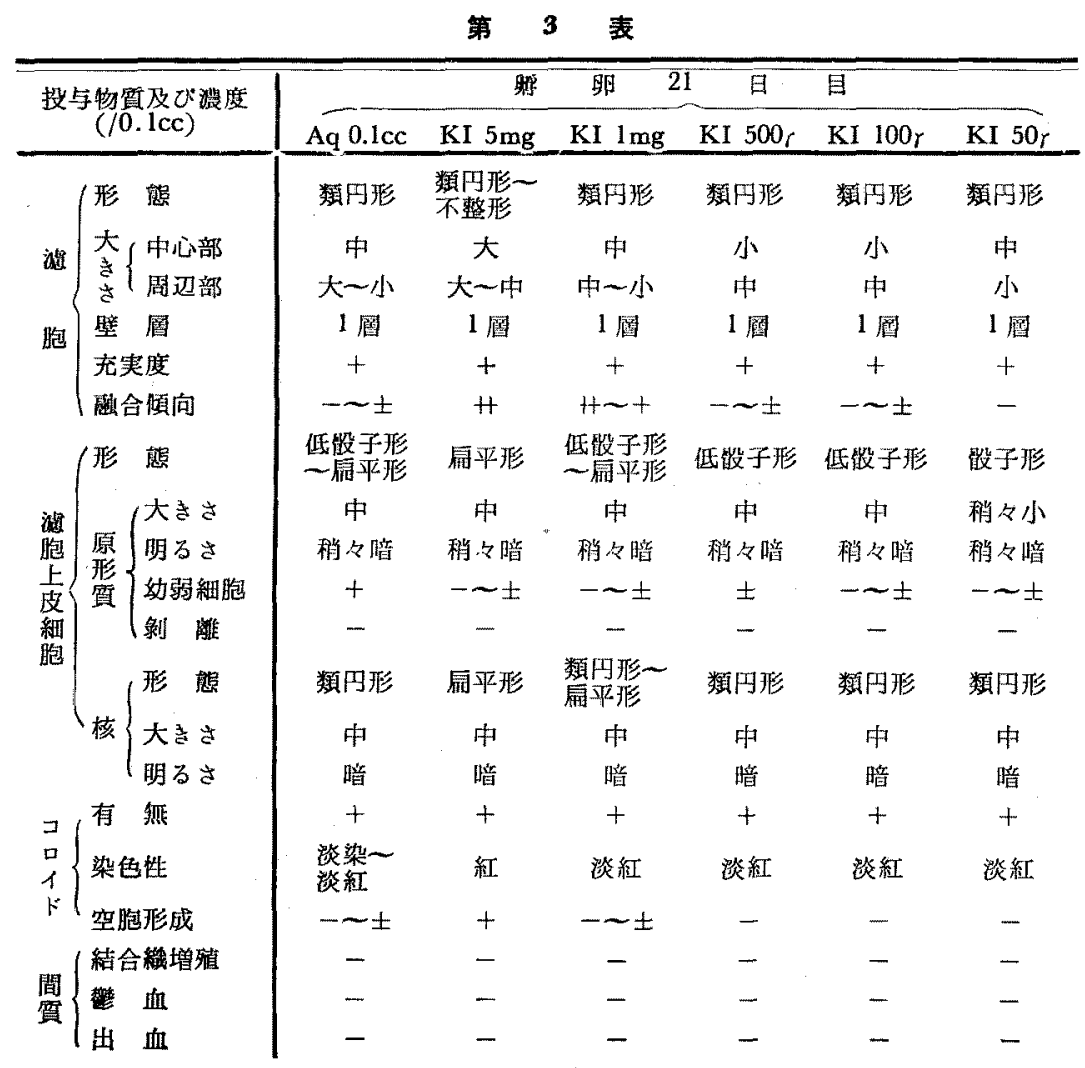




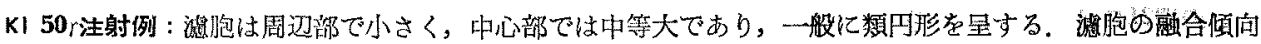

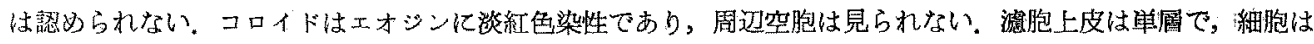

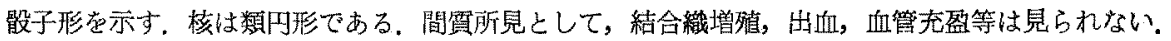

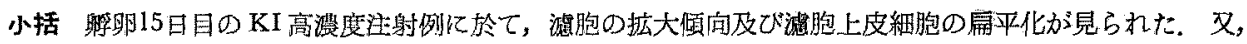

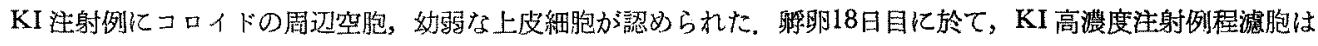

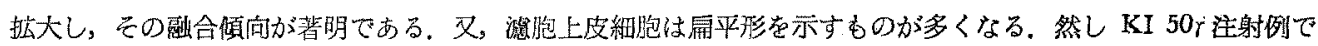
は股子形細胞が多く，胞体は小さい、コロイドは KI の注射量の増加に伴つてさオジ染色珄を增す。間資には

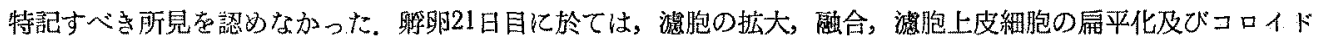

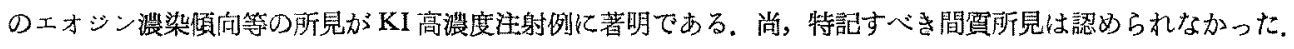

3）濾狍上皮の高き（第 1 图参照）

へマトキシリン・エオシン重染色在施した組織標本の甲状腺滤胞上皮細胞の高さ党 Micrometer 使用して

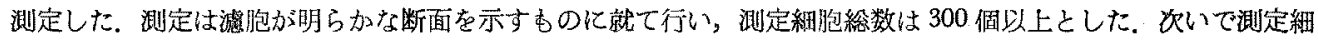
胞総数に刘する，ある测定值（細胞の高さ）の細胞数の百分率を求めて図示した，尚，测定は Aq 注射例，KI $5 \mathrm{mg}, 500 \%$ ，50r注射例に就て夫々行った.

躬卿15日目

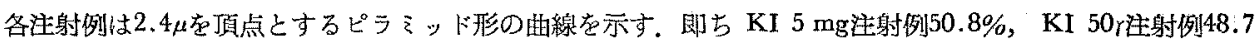
$\%, \mathrm{Aq}$ 注射例 $42.3 \%, \mathrm{KI} 500$ 注射例 $31.4 \%$ の順位を示し, 夫々各注射例の最高率である。 $1.8 \mu$ 以下では Aq

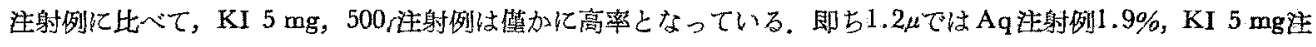

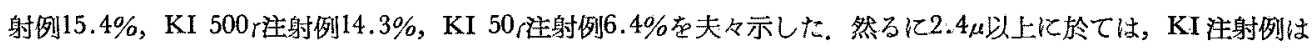
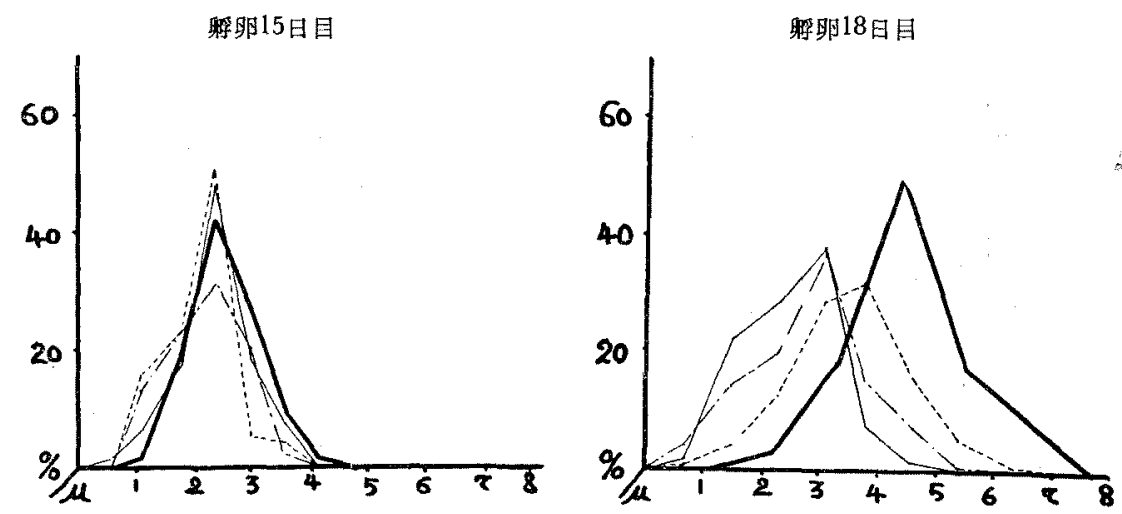

垺卵21日目

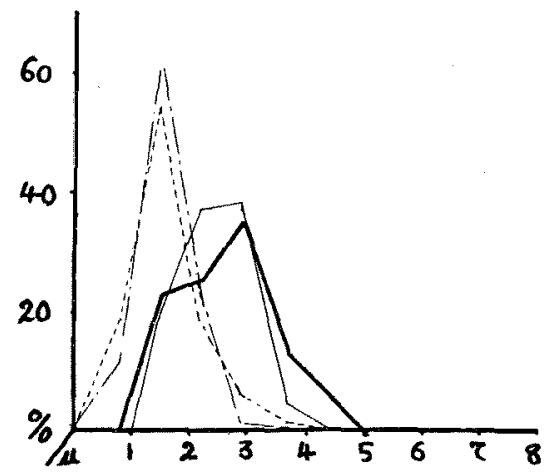

第1図。海胞上皮の高さ。 褂 $: \%=\frac{\text { ある高さの細胞数 }}{\text { 測定絸胞総数 }} \times 100$

$-\mathrm{Aq}$ 注射例

-....... KI $5 \mathrm{mg}$ 注射例

-.. KI 500r注射例

KI 50r注射例 


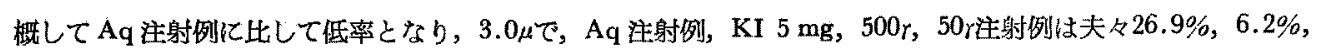
$20.0 \%, 19.2 \%$ を示す。

\section{期卯18日目}

$\mathrm{Aq}$ 注射例は $4.4 \mu て ゙ 50.0 \% ， \mathrm{KI} 5 \mathrm{mg}$ 注射例は $3.8 \mu て ゙ 32.0 \%$ ， 又 KI 500 ,注射例及び KI 50 注射例は $2.2 \mu$

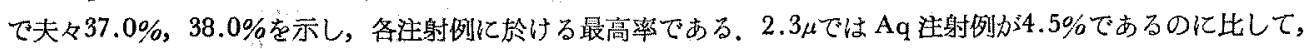
KI $5 \mathrm{mg}, 500 r ， 50$ 注射例仙夫々 $12.5 \% ， 19.8 \% ， 28.7 \%$ を示し，何れも高率である. $4.6 \mu$ 亿於ては，KI $5 \mathrm{mg}$ 注射列 $5.5 \%, \mathrm{KI} 500$ 注射例 $0.8 \%, \mathrm{KI} 50$ 注射例では $0 \%$ で Aq 注射列の $18.4 \%$ 亿比べて何れす低率である。

\section{鹏郋21日目}

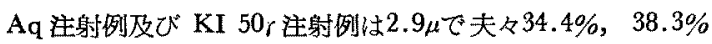

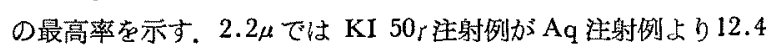

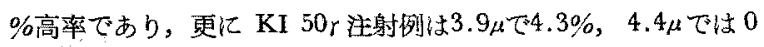
\%を示し，Aq 注射例の $12.5 \% ， 6.3 \%$ 亿比して低率である. KI

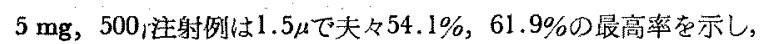
二者とも Aq 注射例化比へて，低い上皮細胞が非常に多くなつて いる.

小括 躬放15日目では KI 注射量の增加に伴って 細胞の高さ

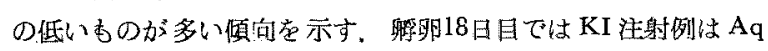
注射例上り古低，細胞が多く，KI 50r，500r，5 mg注射例の順 位で高率走示す。邲师21日目に至り，KI $5 \mathrm{mg} ， 500$ r注射例は共 亿低い細胞が著明に多く，KI 50 注射例虹 Aq 注射例之略々同様 の傾向である. 更に，各注射例に於て最高率を示す細胞の高さ

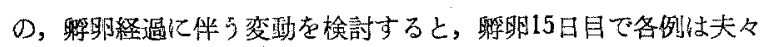
同じ高さを示し，軄卵18日目では何れも高さを增し，㥂郋21日目 亿至つて減少の僋向走している(第 2 図参照).

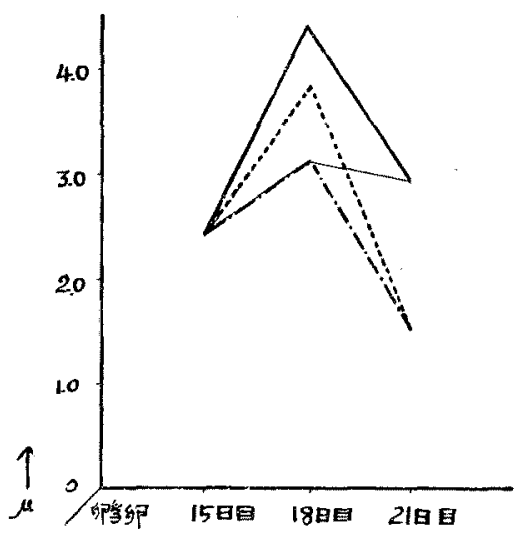

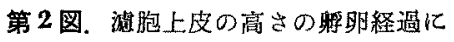
侎亏変動。
Aq 注射例
KI $5 \mathrm{mg}$ 注射例
KI 500 r注射例
KI 50 r注射例

\section{西。甲状腺重量}

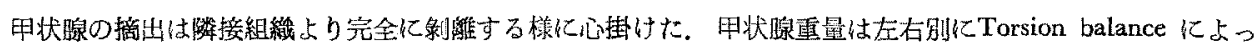

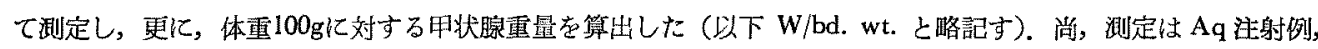
$\mathrm{KI} 5 \mathrm{mg}, 500 r ， 50$ 注射例の夫々に龍て行った。

\section{䀧莭15日目（第 4 表参照）}

$\mathrm{Aq}$ 注射例の $2.4 \mathrm{mg}$ に比べて，KI注射量で结何れも增量する。即ち，KI $5 \mathrm{mg}$ 注射量4.3mg，KI 500 r注射 例 $3.7 \mathrm{mg}, \mathrm{KI} 50$ 注射例で $3.3 \mathrm{mg}$ である.W/bd. wt. は KI $5 \mathrm{mg}, 500$ ， 50 注射例では夫々 $34.7 \mathrm{mg} ， 27.7 \mathrm{mg}$ ， $29.6 \mathrm{mg}$ にして，何れも Aq 注射例の16.0mg 上り高い値である.

第 4 表。用状腺重量。䊩卵15日目。

\begin{tabular}{|c|c|c|c|c|c|c|c|c|}
\hline \multirow{2}{*}{$\begin{array}{l}\text { 投与物賈 } \\
\text { 及び莀度 } \\
(/ 0.1 \mathrm{Icc})\end{array}$} & \multicolumn{4}{|c|}{$\mathrm{Aq} 0.1 \mathrm{cc}$} & \multicolumn{4}{|c|}{ KI $5 \mathrm{mg}$} \\
\hline & 右僛 & 左側 & 糥側 & W/bd. wt. & 右側 & 左側 & 画側 & W/bd. wt. \\
\hline 1 & 2.0 & 2.0 & 4.0 & 13.3 & 2.0 & 2.5 & 4.5 & 34.6 \\
\hline 2 & 1.0 & 1.0 & 2.0 & 17.4 & 2.0 & 2.0 & 4.0 & 36.4 \\
\hline 例 & 1.0 & 1.0 & 2.0 & 14.3 & 1.5 & 2.0 & 3.5 & 26.9 \\
\hline 4 & 1.0 & 1.0 & 2.0 & 16.0 & 2.0 & 2.0 & 4.0 & 29.6 \\
\hline 5 & 0.5 & 1.5 & 2.0 & 19.0 & 2.5 & 3.0 & 5.5 & 45.8 \\
\hline 平均犆 & 1.1 & 1.3 & 2.4 & 16.0 & 2.0 & 2.3 & 4.3 & 34.7 \\
\hline
\end{tabular}


68

\begin{tabular}{|c|c|c|c|c|c|c|c|c|}
\hline \multirow{2}{*}{ 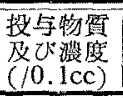 } & \multicolumn{4}{|c|}{ KI $500_{r}$} & \multicolumn{4}{|c|}{$\mathrm{KI} 50 r$} \\
\hline & 右買 & 左制 & 画俪 & W/bd. wt. & 右側 & 左側 & 西側 & W/bd. wt. \\
\hline \multirow{6}{*}{ 例 } & 2.0 & 2.5 & 4.5 & 37.5 & 1.0 & 1.5 & 2.5 & 20.8 \\
\hline & 2.5 & 2.0 & 4.5 & 36.0 & 2.5 & 2.0 & 4.5 & 45.0 \\
\hline & 1.5 & 2.0 & 3.5 & 26.9 & 1.5 & 2.0 & 3.5 & 25.0 \\
\hline & 2.0 & 2.0 & 4.0 & 25.0 & 2.0 & 2.0 & 4.0 & 38.1 \\
\hline & 1.0 & 1.0 & 2.0 & 13.3 & 1.0 & 1.0 & 2.0 & 19.0 \\
\hline & 1.8 & 1.9 & 3.7 & 27.7 & 1.6 & 1.7 & 3.3 & 29.6 \\
\hline
\end{tabular}

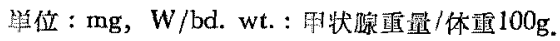

\section{卯卵18日目(第 5 表参照)}

甲状腺の 平均重量及び W/bd. wt. は，Aq 注射例 $03.4 \mathrm{mg} ， 17.9 \mathrm{mg}$ 亿比して，KI $5 \mathrm{mg}$ 注射例7.4 $\mathrm{mg}$,

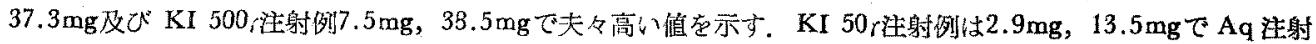
例のをれをりも低い.

第 5 表、日状腺重量，稃卵18日目。

\begin{tabular}{|c|c|c|c|c|c|c|c|c|}
\hline \multirow{2}{*}{ 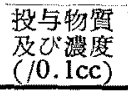 } & \multicolumn{4}{|c|}{$\mathrm{Aq} 0.1 \mathrm{cc}$} & \multicolumn{4}{|c|}{ KI $5 \mathrm{mg}$} \\
\hline & 右㑡 & 左側 & 画側 & W/bd. wt. & 右側 & 左側 & 雨側 & W/bd. wt. \\
\hline & 2.0 & 2.0 & 4.0 & 19.0 & 4.0 & 3.5 & 7.5 & 39.5 \\
\hline & 1.0 & 1.0 & 2.0 & 10.8 & 4.0 & 6.0 & 10.0 & 47.6 \\
\hline & 1.0 & 1.5 & 2.5 & 11.9 & 3.5 & 4.5 & 8.0 & 38.1 \\
\hline & 2.0 & 2.0 & 4.0 & 18.2 & 2,0 & 3.5 & 5.5 & 33.3 \\
\hline & 1.0 & 2.0 & 3.0 & 12.0 & 2.5 & 5.0 & 7.5 & 32.6 \\
\hline & 1.5 & 1.5 & 3.0 & 17.1 & 3.5 & 4.5 & 8.0 & 40.0 \\
\hline & 1,5 & 2.0 & 3.5 & 20.3 & 4.0 & 4.0 & 8.0 & 34.4 \\
\hline & 2.0 & 1.5 & 3.5 & 21.9 & 2.0 & 2.0 & 4.0 & 18.2 \\
\hline & 2.0 & 3.0 & 5,0 & 25.0 & 2.0 & 3.0 & 5.0 & 30.3 \\
\hline 110 & 1.0 & 2.0 & 3.0 & 23.1 & 4.0 & 6.0 & 10.0 & 58.8 \\
\hline 平均值 & 1.6 & 1.7 & 3.4 & 17.9 & 3.2 & 4.2 & 7.4 & 37.3 \\
\hline \multirow{2}{*}{ 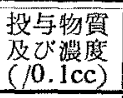 } & \multicolumn{4}{|c|}{ KI $500 r$} & \multicolumn{4}{|c|}{ KI $50 r$} \\
\hline & 右符 & 左側 & 面側 & W/bd. wt. & 右側 & 左側 & 雨偡 & W/bd. wt. \\
\hline 1 & 2.5 & 3.0 & 5.5 & 29.7 & 1.5 & 2.0 & 3.5 & 15.2 \\
\hline 2 & 5.0 & 5.0 & 10.0 & 54.1 & 1.0 & 1.5 & 2.5 & 11.4 \\
\hline 3 & 2.0 & 4.0 & 6.0 & 26.7 & 1.5 & 2.0 & 3.5 & 14.6 \\
\hline 4 & 3.5 & 5.0 & 8.5 & 38.6 & 1.0 & 2.0 & 3.0 & 14.3 \\
\hline 5 & 2.5 & 3.5 & 6.0 & 28.6 & 1.5 & 2.0 & 3.5 & 18.4 \\
\hline 6 & 3.0 & 4.0 & 7.0 & 42.4 & 1.0 & 1.0 & 2.0 & 9.5 \\
\hline 7 & 3.0 & 4.0 & 7.0 & 38.1 & 1.0 & 1.0 & 2.0 & 9.2 \\
\hline 8 & 3.5 & 5.5 & 9.0 & 47.4 & 1.5 & 2.0 & 3.5 & 15.2 \\
\hline 9 & 4.0 & 5.0 & 9.0 & 46.2 & & & & \\
\hline 10 & 2.5 & 4.0 & 6.5 & 33.3 & & & & \\
\hline 平均值 & 3.1 & 4.6 & 7.5 & 38.5 & 1.3 & 1.7 & 2.9 & 13.5 \\
\hline
\end{tabular}

単位 : mg，W/bd. wt. : 甲状腺電量/体重 $100 \mathrm{~g}$. 
明21日目 (第 6 表参照)

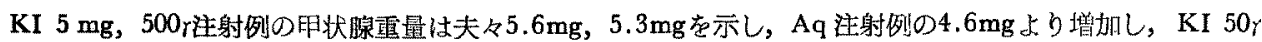
注射列 $3.8 \mathrm{mg}$ は Aq 注射例々り減量する。W/bd. wt. は Aq 注射例の13.9mg より KI $5 \mathrm{mg}$ ，500r注射例で夫々 $18.3 \mathrm{mg}, 15.4 \mathrm{mg}$ と高く，KI $50 \mathrm{r}$ 注射例は $12.2 \mathrm{mg}$ と低い值を示す。

第 6 表. 甲状腺重量，娐卵21日目。

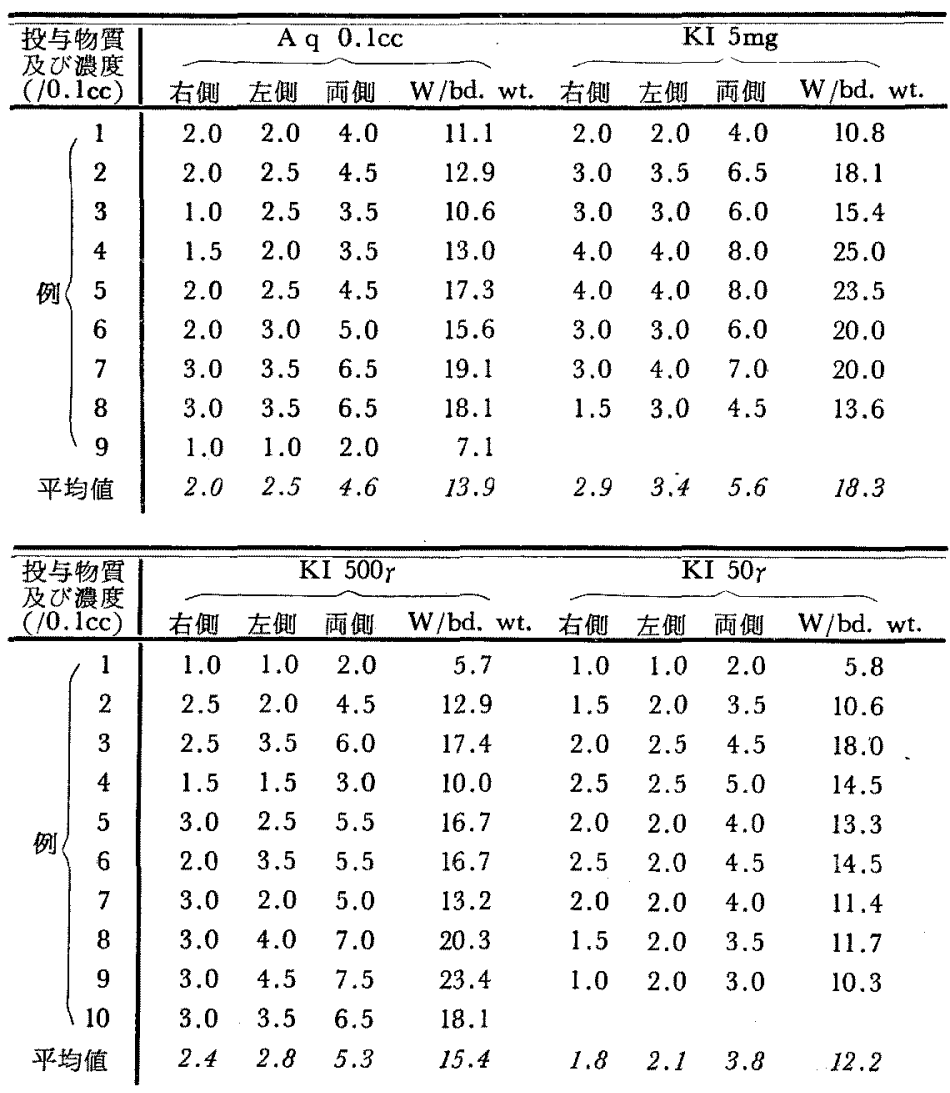

単位: mg, W/bd. wt. : 甲状腚重量/体重 $100 \mathrm{~g}$.

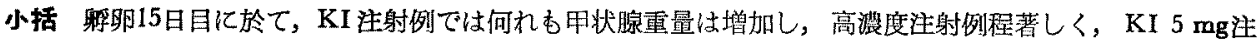
射例てはAq 注射例の甲状腚重量の183\%に当る. 又 W/bd. wt. はAq 注射例に比して KI 注射例は73〜117\%增

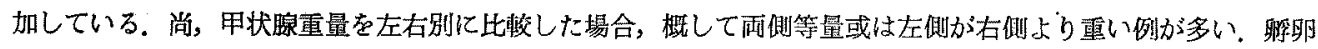
18 日目に於て，KI $5 \mathrm{mg} ， 500$ 注射例の平均甲状腺重量は Aq 注射例に比して118\%增加し，KI 50 r注射例では 12\%の娍少を示した. KI $5 \mathrm{mg}, 500$ r注射例に於ける W/bd. wt. はAq 注射例の208\%，214\%に当る．KI $50 r$ 注射例では Aq 注射例上り25\%減少した，尚，左側甲状腺重星が右僛上り大きい晹合が多く，その頻度はAq 注 射例飞於て $30 \%$ ，KI $5 \mathrm{mg}$ 注射例で70\%，KI 500r注射例で90\%，KI 50r注射例では70\%であった，卯䀦21日目 亿至ると，KI $5 \mathrm{mg} ， 500$ 注射例の平均甲状腺重量は Aq 注射例より30\%，13\%堌加し，KI $50 r$ 注射例では30\%

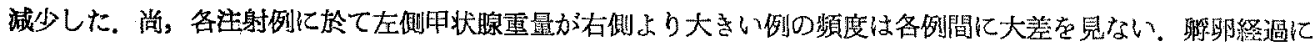
伴う甲状腺重量の変動を検討すると，Aq 注射例では摡卵経過に伴って䀩々直線的に增冝するが，KI $5 \mathrm{mg}, 500 r$

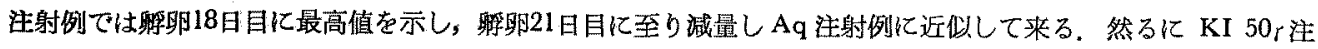

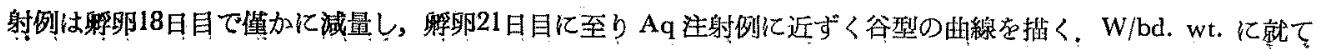




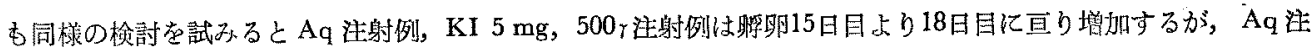

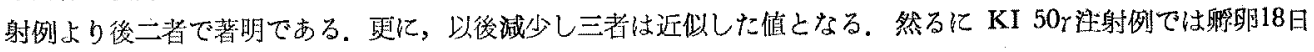
目，21日目と沿次娍量している(第 3 図参照）。

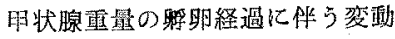

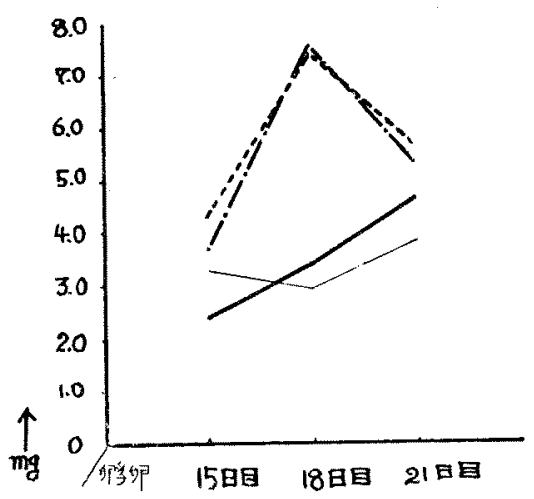

W/bd. wt. ○涉畉経過に伴う変動

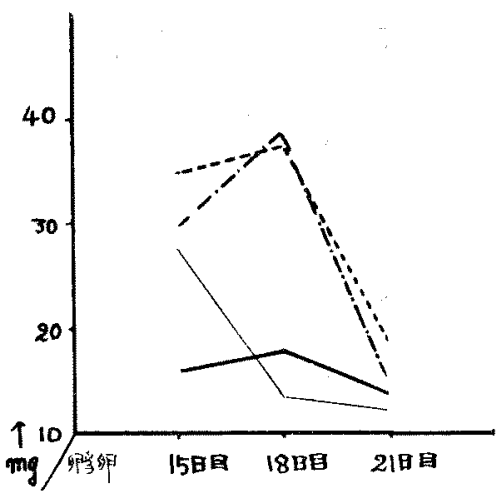

第 3 図，甲状腺重量. 補：W/bd. wt. : 甲状腚重量/体西 $100 \mathrm{~g}$.

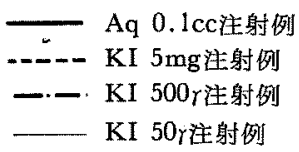

V. 尿霞水量及び $\mathrm{pH}$ 值（第 7 表参照）

\section{䁌卵15日昌}

$\mathrm{Aq}$ 注射例 $8.2 \mathrm{cc}$ 対し，KI $5 \mathrm{mg} ， 500 \mathrm{r} ， 50$ r注射例は夫々 $8.0 \mathrm{cc} ， 7.4 \mathrm{cc} ， 7.8 \mathrm{cc}$ あっった。 $\mathrm{pH}$ 值は Aq 注

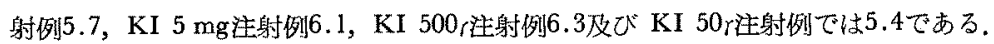

\section{潭邭18日目}

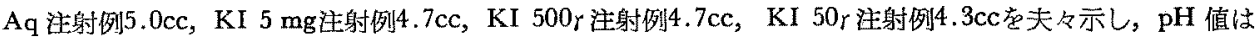
夫々 $5.8,6.2,5.6,6.10$ 酸性值である.

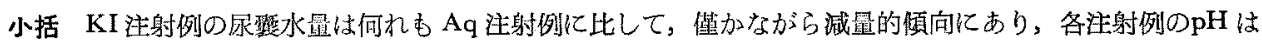
值 6 前後である。

第 7 表。尿翼水及び羊水。

\begin{tabular}{|c|c|c|c|c|c|c|c|c|}
\hline \multirow{3}{*}{ 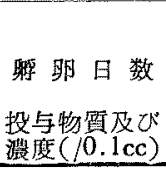 } & \multicolumn{4}{|c|}{ 厡霆水 } & \multicolumn{2}{|r|}{ 羊 } & \multicolumn{2}{|l|}{ 水 } \\
\hline & \multicolumn{2}{|c|}{ 15日目 } & \multicolumn{2}{|c|}{ 18日目 } & \multicolumn{2}{|c|}{ 15日目 } & \multicolumn{2}{|c|}{ 18日目 } \\
\hline & $\begin{array}{l}\text { 総嗄 } \\
\text { (cc) }\end{array}$ & $\mathrm{pH}$ & 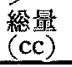 & $\mathrm{pH}$ & $\begin{array}{l}\text { 総量 } \\
(\mathrm{cc}) \\
\end{array}$ & $\mathrm{pH}$ & $\begin{array}{l}\text { 総量 } \\
\text { (cc) }\end{array}$ & $\mathrm{pH}$ \\
\hline \multirow{5}{*}{$\begin{array}{l}\mathrm{A} \mathrm{q} \\
0.1 \mathrm{cc}\end{array}$} & 8.0 & 5.4 & 4.0 & 5.8 & 1.0 & 7.4 & 0.2 & 7.6 \\
\hline & 6.7 & 5.0 & 6.0 & 5.8 & 2.3 & 7.4 & 0.4 & 8.0 \\
\hline & 6.5 & 5.6 & 6.1 & 5.4 & 0.8 & 7.4 & 1.5 & 8.4 \\
\hline & 10.5 & 6.2 & 3.5 & 6.8 & 1.5 & 7.0 & 0.3 & 8.4 \\
\hline & 9.5 & 6.4 & 5.4 & 5.0 & 1.5 & 7.2 & 0.3 & 8.0 \\
\hline 平均 值 & 8.2 & 5.7 & 5.0 & 5.8 & 1.4 & 7.3 & 0.5 & 8.1 \\
\hline
\end{tabular}




\begin{tabular}{|c|c|c|c|c|c|c|c|c|c|}
\hline \multirow{3}{*}{ KI } & 11 & 8.3 & 5.8 & 5.6 & 6.8 & 1.0 & 7.4 & 0.5 & 8.6 \\
\hline & 2 & 10.0 & 8.4 & 3.0 & 5.8 & 1.4 & 7.4 & 2.0 & 7.6 \\
\hline & 例 & 8.8 & 5.4 & 6.4 & 6.2 & 1.9 & 7.2 & 3.0 & 7.6 \\
\hline $5 \mathrm{mg}$ & 4 & 6.3 & 5.4 & 3.3 & 6.4 & 1.5 & 7.0 & 1.0 & 8.2 \\
\hline & 15 & 6.7 & 5.6 & 5.0 & 6.8 & 2.0 & 7.4 & 2.0 & 8.4 \\
\hline 平 & 均 值 & 8.0 & 6.1 & 4.7 & 6.2 & 1.6 & 7.3 & 1.7 & 8.1 \\
\hline & 1 & 8.0 & 5.8 & 5.0 & 5.8 & 3.1 & 6.8 & 1.0 & 7.4 \\
\hline KI & 2 & 6.9 & 6.0 & 4.5 & 5.8 & 2.8 & 7.4 & 0.5 & 8.6 \\
\hline & 例 & 8.0 & 7.8 & 6.0 & 5.4 & 2.8 & 6.2 & 1.0 & 7.6 \\
\hline $500 \gamma$ & 4 & 8.7 & 6.4 & 3.5 & 5.8 & 2.0 & 7.0 & 0.4 & 8.6 \\
\hline & 15 & 5.6 & 5.4 & 4.6 & 5.4 & 5.3 & 6.0 & 0.2 & 8.4 \\
\hline 平 & 均 值 & 7.4 & 6.3 & 4.7 & 5.6 & 3.2 & 6.7 & 0.6 & 8.1 \\
\hline & 1 & 8.5 & 5.0 & 5.5 & 6.2 & 4.2 & 6.6 & 1.0 & 8.6 \\
\hline KI & 2 & 8.0 & 5.0 & 2.7 & 6.0 & 2.5 & 6.8 & 0.5 & 7.8 \\
\hline & 例 & 8.5 & 6.0 & 5.8 & 7.2 & 2.2 & 8.6 & 0.2 & 8.6 \\
\hline $50 ?$ & 4 & 7.3 & 5.8 & 4.0 & 5.4 & 2.5 & 7.4 & 0.2 & 8.4 \\
\hline & 5 & 6.5 & 5.4 & 3.5 & 5.8 & 2.2 & 6.2 & 0.5 & 8.4 \\
\hline II & 均 值 & 7.8 & 5.4 & 4.3 & 6.1 & 2.7 & 7.1 & 0.5 & 8.4 \\
\hline
\end{tabular}

\section{V．羊水量及び pH 值（第７表参照）}

邪期15日目

Aq 注射例の $1.4 \mathrm{cck}$ 比して，KI $5 \mathrm{mg}$ 注射例 $1.6 \mathrm{cc}$, KI $500 \mathrm{r}$ 注射例 $3.2 \mathrm{cc}, \mathrm{KI} 50_{r}$ 注射例 $2.7 \mathrm{cc}$ と増量的傾 问を示す， $\mathrm{pH}$ 值は $\mathrm{Aq}$ 注射例及び $\mathrm{KI}$ $5 \mathrm{mg}, 50$ 注射例は各々 $7.3,7.3,7.1$ で，KI 50r在射例のみか酸性倠の6.7 でする。

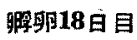

$\mathrm{KI} 5 \mathrm{mg}$ 注射例 $1.7 \mathrm{cc}$ \& Aq 注射 例0.5ccよb堌し，KI 500r，50r注射 例は夫々0.6cc，0.5cct示亦。 $\mathrm{pH}$ 值 は Aq 注射例，KI $5 \mathrm{mg} ， 500 r ， 50 r$
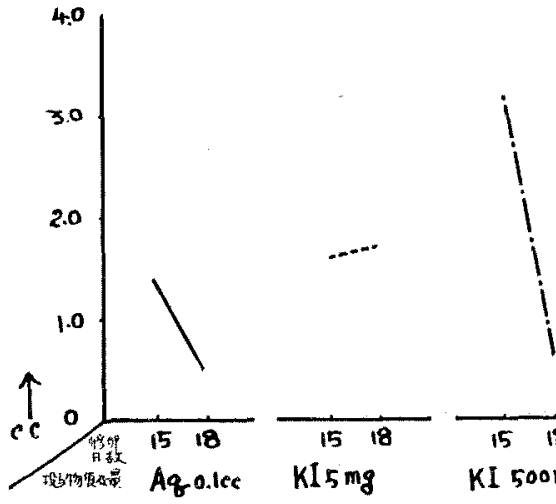

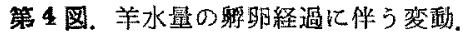

注射例は夫々8.1，8.1，8.1，8.4である。

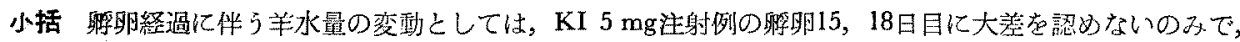
他の注射列で明らかに娍少した（第 4 図参照）。

\section{VI. 体重（第 8 表参照）}

\section{盽卯15日目}

$\mathrm{Aq}$ 注射例の11.8gk比して，KI $5 \mathrm{mg}$ 注射例は $12.2 \mathrm{~g} ， \mathrm{KI} 500 r$ 注射例 $13.4 \mathrm{~g}$ と增加し，KI $50 r$ 注射例では $11.4 \mathrm{~g}$ 示した。

\section{睡郋18日目}

KI $5 \mathrm{mg} ， 500 \mathrm{r} ， 50$ r注射例は夫々 $19.4 \mathrm{~g} ， 19.9 \mathrm{~g} ， 22.0 \mathrm{~g}$ で网れも Aq 注射例に於ける19.1gより增悬した，

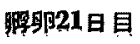




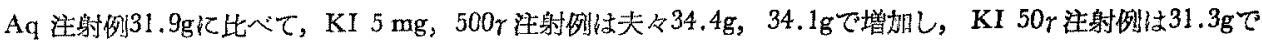
ある。

小括 $\mathrm{Aq}$ 注射例に比して KI $5 \mathrm{mg} ， 500$ 注射例は增量的であり，KI 50r注射例は摡卵18日目に增加した。

第 8 表. 佮 重.

\begin{tabular}{|c|c|c|c|c|c|c|c|c|c|c|c|c|}
\hline 鋰卵日数 & & 15 & 目 & & & 18 & 目 & & & 21 & 目 & \\
\hline 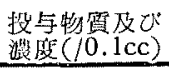 & $\begin{array}{c}\mathrm{A} \mathrm{q} \\
0.1 \mathrm{cc} \\
\end{array}$ & $\begin{array}{r}\mathrm{KI} \\
5 \mathrm{rmg}\end{array}$ & $\begin{array}{c}\mathrm{KI} \\
500 r \\
\end{array}$ & $\begin{array}{r}\mathrm{KI} \\
50 r \\
\end{array}$ & $\begin{array}{c}\mathrm{A} \mathrm{q} \\
0.1 \mathrm{cc} \\
\end{array}$ & $\begin{array}{r}\mathrm{KI} \\
5 \mathrm{mg} \\
\end{array}$ & $\begin{array}{c}\mathrm{KI} \\
500_{r} \\
\end{array}$ & $\begin{array}{r}\mathrm{KI} \\
50 r \\
\end{array}$ & $\begin{array}{c}\mathrm{A} \mathrm{q} \\
0.1 \mathrm{cc} \\
\end{array}$ & $\begin{array}{r}\mathrm{KI} \\
5 \mathrm{mg}\end{array}$ & $\begin{array}{c}\mathrm{KI} \\
500_{r}\end{array}$ & $\begin{array}{r}\mathrm{KI} \\
50 r \\
\end{array}$ \\
\hline 1 & 9.0 & 12.5 & 12.0 & 10.2 & 17.5 & 20.0 & 16.5 & 22.1 & 32.0 & 30.0 & 33.0 & 31.0 \\
\hline 2 & 14.0 & 11.7 & 13.6 & 12.2 & 17.2 & 18.0 & 22.0 & 21.8 & 34.0 & 34.0 & 38.0 & 35.0 \\
\hline 3 & 10.2 & 12.0 & 13.7 & 11.6 & 16.0 & 22.0 & 19.0 & 23.0 & 36.0 & 35.0 & 34.5 & 30.0 \\
\hline 4 & 12.2 & 11.8 & 13.8 & 12.0 & 20.0 & 16.5 & 19.5 & 22.0 & 28.0 & 33.0 & 32.0 & 29.0 \\
\hline 5 & 12.1 & 11.7 & 12.5 & 10.0 & 13.0 & 17.0 & 18.5 & 24.0 & 36.0 & 37.0 & 36.0 & 34.0 \\
\hline 6 & 12.0 & 13.0 & 12.0 & 14.0 & 21.0 & 19.0 & 18.5 & 21.0 & 35.0 & 36.0 & 35.0 & 33.0 \\
\hline 7 & 11.5 & 11.0 & 12.5 & 10.5 & 18.5 & 21.0 & 22.5 & 23.0 & 33.0 & 39.0 & 34.5 & 25.0 \\
\hline 8 & 14.0 & 13.0 & 13.0 & 10.5 & 21.0 & 21.0 & 22.0 & 19.0 & 27.0 & 32.0 & 30.0 & 34.5 \\
\hline 9 & 12.5 & 13.5 & 16.0 & & 22.0 & 16.5 & 19.5 & & 26.0 & 34.0 & 33.0 & 30.0 \\
\hline 10 & 10.5 & 12.0 & 15.0 & & 25.0 & 23.0 & 21.0 & & & & 35.0 & \\
\hline 平均倠 & 11.8 & 12.2 & 13.4 & 11.4 & 19.1 & 19.4 & 19.9 & 22.0 & 31.9 & 34.4 & 34.1 & 31.3 \\
\hline
\end{tabular}

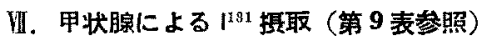

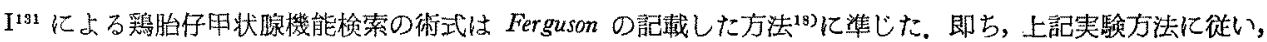

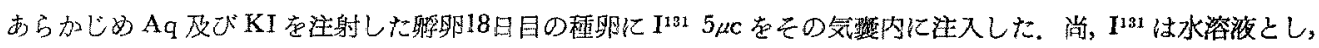

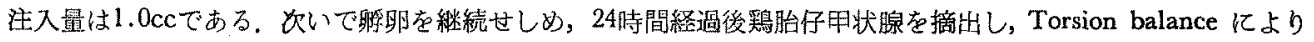

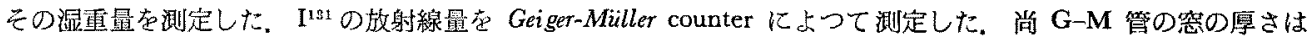

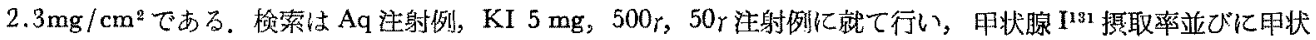
眿羊位重量 (mg) 当りの $I^{131}$ 摄取量を算出した。

\section{Aq 注射例}

第 9 表. 甲状腚による $I^{131}$ 提取。

\begin{tabular}{|c|c|c|c|c|c|c|c|c|c|c|c|c|}
\hline \multirow{2}{*}{$\begin{array}{l}\text { 投与物䨢 } \\
\text { 及び漫度 } \\
(10.1 \mathrm{cc})\end{array}$} & \multicolumn{3}{|c|}{$\mathrm{A} \mathrm{q} 0.1 \mathrm{cc}$} & \multicolumn{3}{|c|}{$\mathrm{KI} 5 \mathrm{mg}$} & \multicolumn{3}{|c|}{ KI $500 r$} & \multicolumn{3}{|c|}{$\mathrm{KI} 50 \gamma$} \\
\hline & $\begin{array}{c}\text { 摄取率 } \\
(\%)\end{array}$ & $\begin{array}{l}\text { 綮取星 } \\
(\mathrm{GPM})\end{array}$ & $\frac{\text { 摄取量 }}{\text { 重量 }}$ & $\begin{array}{c}\text { 提取率 } \\
(\%)\end{array}$ & $\begin{array}{l}\text { 摄取量 } \\
(\mathrm{CPPM})\end{array}$ & 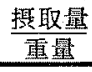 & $\begin{array}{c}\text { 振取率 } \\
(\%)\end{array}$ & $\begin{array}{l}\text { 摄取量 } \\
\text { (CPM) }\end{array}$ & 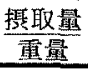 & $\begin{array}{c}\text { 抎取率 } \\
(\%)\end{array}$ & $\begin{array}{l}\text { 㩑取量 } \\
\text { (CPM) }\end{array}$ & 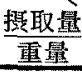 \\
\hline 1 & 6.4 & 191 & 27 & 0.3 & 8 & 0.4 & 4.5 & 134 & 8 & 12.6 & 376 & 31 \\
\hline 2 & 20.6 & 616 & 123 & 0.3 & 8 & 0.5 & 2.1 & 63 & 4 & 7.8 & 232 & 42 \\
\hline 3 & 13.8 & 415 & 92 & 0.2 & 6 & 0.3 & 1.6 & 47 & 5 & 10.3 & 307 & 51 \\
\hline 4 & 17.2 & 515 & 74 & 0.5 & 15 & 0.7 & 1.4 & 43 & 7 & 18.6 & 555 & 43 \\
\hline 5 & 26.8 & 802 & $1 \in 0$ & 0.2 & 7 & 0.5 & 1.2 & 37 & 4 & 17.7 & 529 & 71 \\
\hline 夘 & 8.4 & 252 & 84 & 0.3 & 9 & 0.8 & 4.4 & 132 & 6 & 10.3 & 307 & 74 \\
\hline 7 & 16.9 & 505 & 84 & 0.03 & 1 & 0.03 & 1.7 & 48 & 3 & 9.1 & 273 & 32 \\
\hline 8 & 12.2 & 365 & 61 & 0.5 & 14 & 1.6 & 1.0 & 30 & 3 & 13.3 & 388 & 31 \\
\hline 9 & 12.5 & 374 & 83 & 0.03 & 1 & 0.1 & 1.7 & 50 & 6 & 8.2 & 244 & 24 \\
\hline 10 & 12.4 & 371 & 62 & & & & & & & & & \\
\hline \multirow[t]{2}{*}{ 平均值 } & 14.7 & 441 & 85 & 0.3 & 8 & 0.5 & 2.2 & 65 & 5.1 & 12.0 & 357 & 44 \\
\hline & \multicolumn{12}{|c|}{ 摄取量 } \\
\hline
\end{tabular}




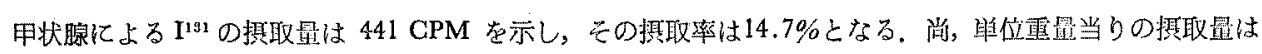
85 CPM である.

\section{KI 注射例}

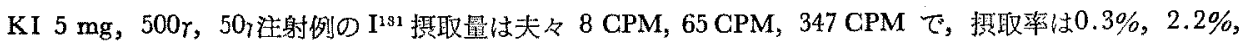

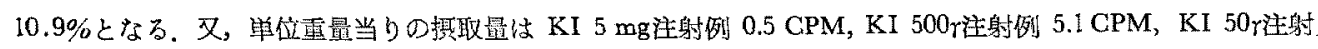
例 44.0 CPM 示す.

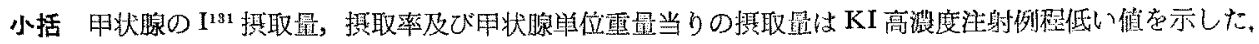
特に，KI $5 \mathrm{mg}$ 注射例の鵎胎仔甲状腺は殆ど ${ }^{131}$ を摄取していないと考らられる。

\section{総括及び考察}

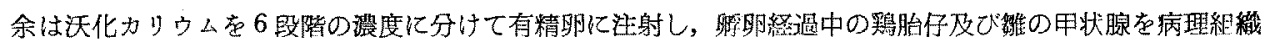

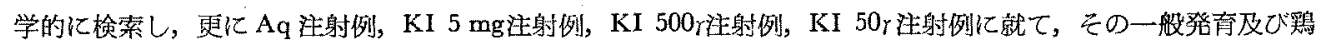
胎仔甲状腺による $\mathbf{I}^{131}$ 撕取状態を吟味した。

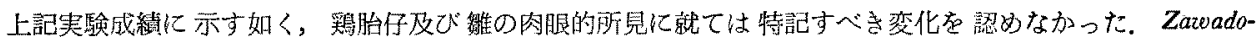

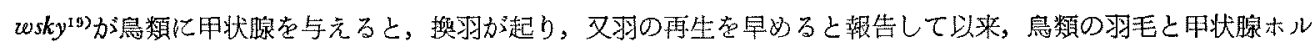

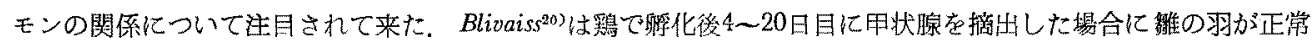

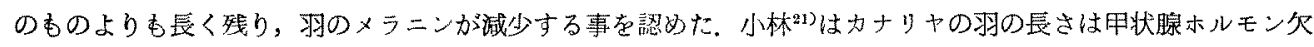
乏の場合でも，過剩の場合でも娍少する傾问にあるが，羽軲 $1 \mathrm{~cm}$ あたりの羽枝数は，チロキシン鳥では娍少す

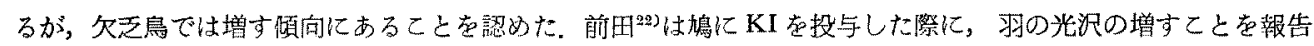

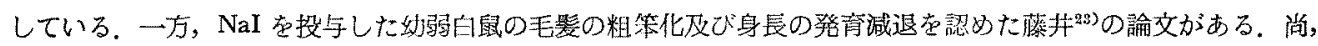

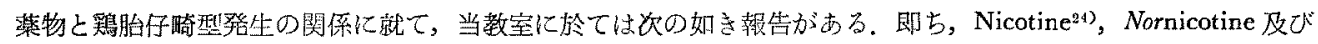

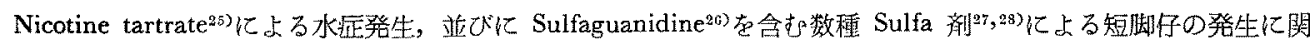
する諭文でする。

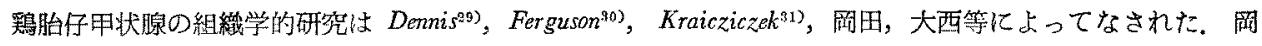

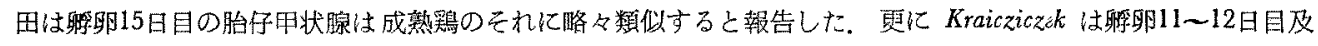
び18日目の胎仔甲状腺は一洔的で然も可逆幽の機能元進を示すと述べている。

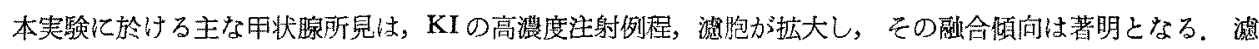

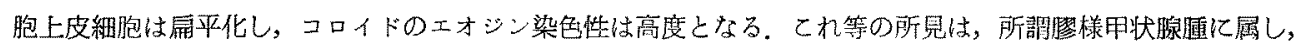

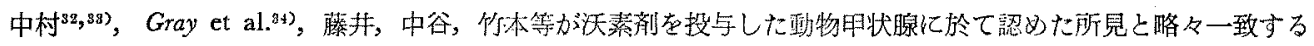
あのである。

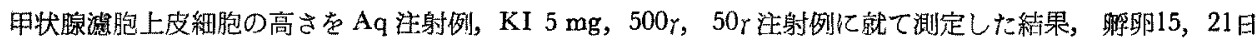

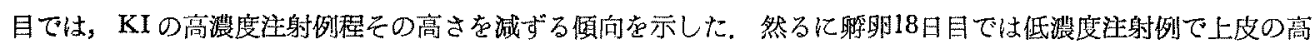

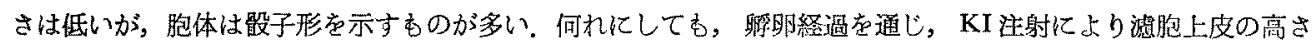
の堿少が認められた。

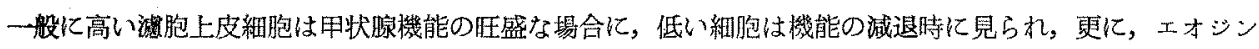
に淡紅色可染生のコロイドは甲状腚機能の活性，櫒深紅色可染性のコロイドは不活性㴼抱を意味すると云われて いる ${ }^{35}$. 狩野 ${ }^{36)}$ は正常人の甲状腺䍇胞上皮の如何なる形の細胞も一般に小さく，機能元進の場合には大きいと述

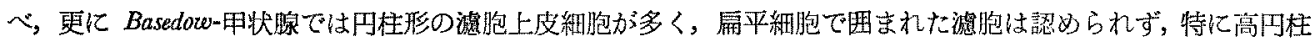

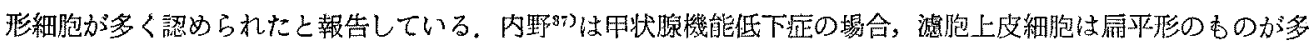

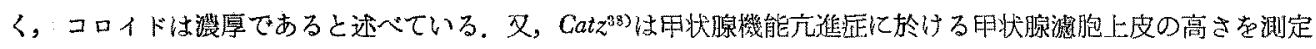

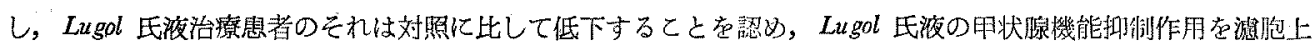
皮の高さより明らがした。

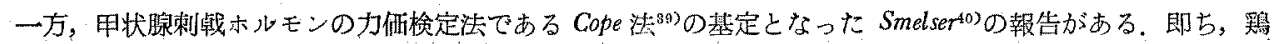




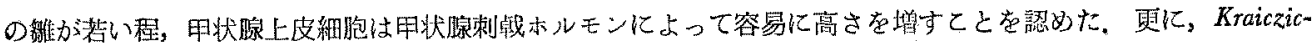

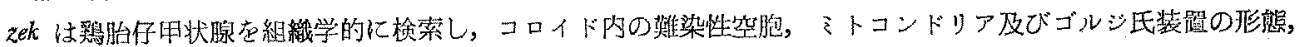

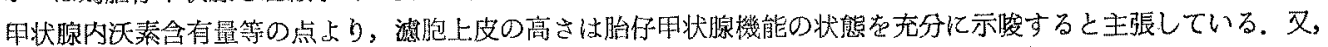

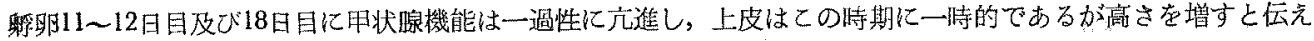

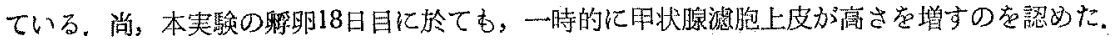

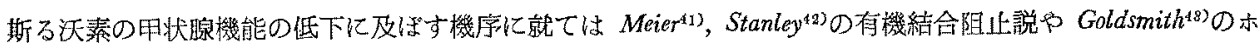
ルモン分泌抑倁説等の諸説が挙げられ，未だ明らかでないと謂われる。

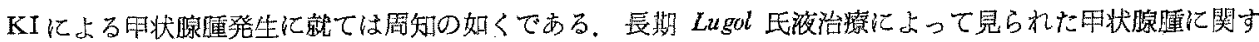

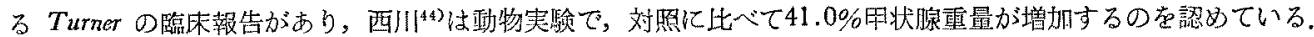

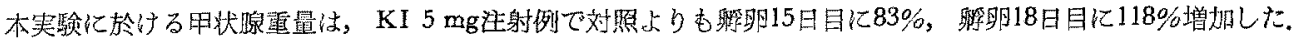

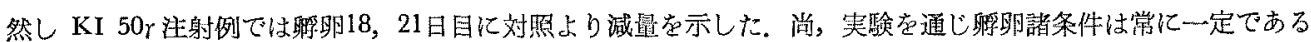

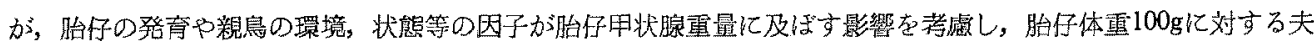

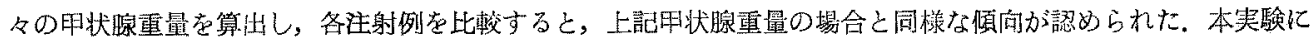

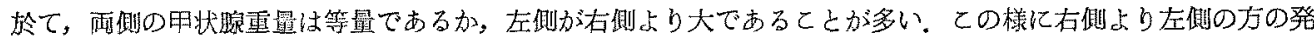

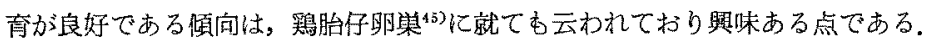

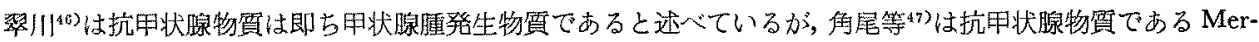
cazole 100 r 注射壆胎仔の甲状腺は著明に腫大し， その重量は刘照の約 6 倍に当ると報告した，松本等は同甲状 腺の㴧胞上皮細胞は增殖し，コロイドは减少すると発表したが，明らかに KI 胛状腺腫の紹織像は Mercazole 甲

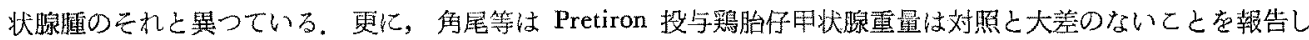

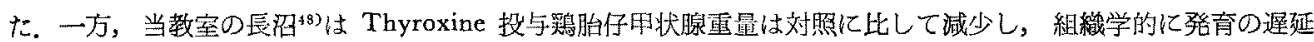
を認妨た，又，岡田は Thyradin 投与鴊胎仔の甲状腺は小さく，濾胞上皮細胞は沜平形䎲して，コロイドはエオ シン得く染色すると述べいる。

本实験の KI 注射鷄胎仔体重は，醥卵15，18日目に於て KI 50 r注射例が Aq 注射例に比べて減少したが，他 の例では堌加の㑯向を示し，前田の KI 投与鳵に於ける体重の成結と略々一致した，又，本実験に於ける尿垔水

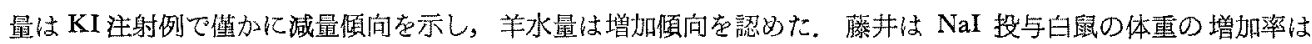

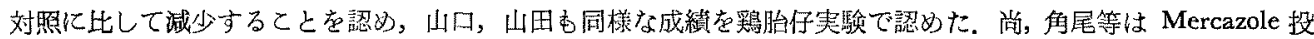

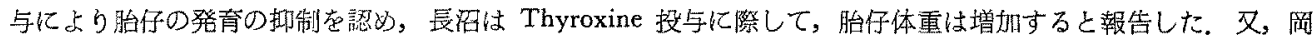

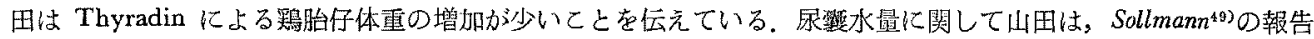

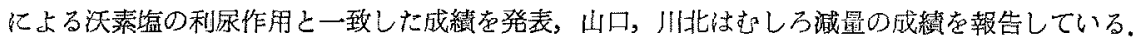

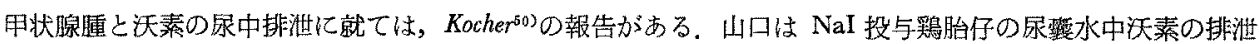

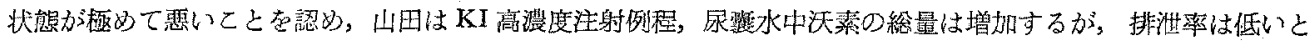

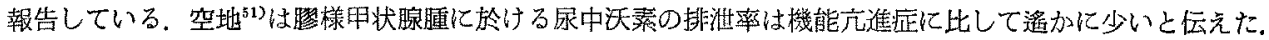

1938年 Hert $z^{52}$ は放射性沃素を沃素代謝の研究に利用し，甲状腺む沃素を高度に提取することを認めた。 こ

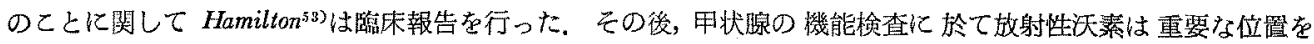
占め，諸種の検索法が挙げられて来た，この内，甲状腚の ${ }^{181}$ 掑取率は機能充進に際して高率上なり，機能低下

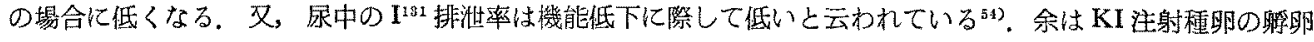

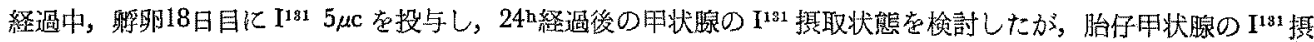
取率及び甲状腺単位重量当りの I191 摄取量㹥 KI 高濃度注射例で低く，特に KI $5 \mathrm{mg}$ 注射例では殆ど掑取されて

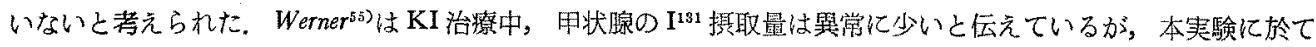
は，KI の投与量の增加䎲伴って甲状腺の $\mathrm{I}^{131}$ 摄取量の著明な墄少を示し，二者間に類似の姿が窥われる。角尾等 は Mercazol 投与鵎胎仔甲状腺の $I^{181}$ 摄取率は対照より高率であるが，甲状腺早位重最当りの摄取率は少く，更 に Thyroxine 投与の埸合の $\mathbf{I}^{131}$ 掑取率及び単位重量当りの摄取量は対照より少く, Pretiron の場合の $\mathbf{I}^{132}$ 摄取

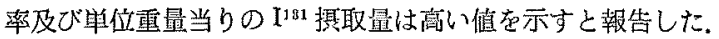

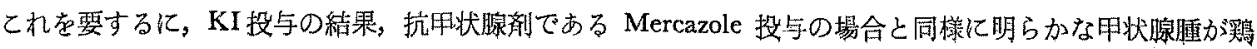




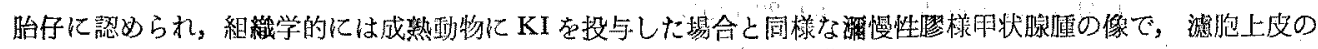

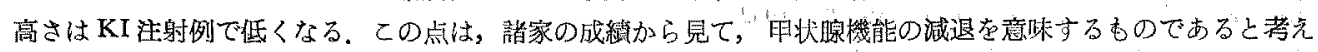
られる。然るに KIによる鴊胎仔の畸型発生は見られず，又一般発育す概して障榑を受けていない点から，甲状

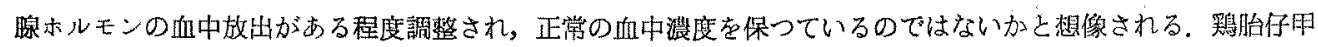

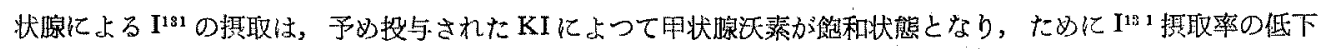
が起ったものと思われる。

\section{結 論}

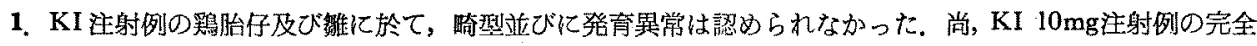
躬化には成功しなかった。

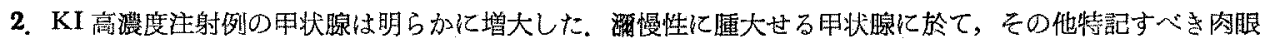
的変化は認められなかった。

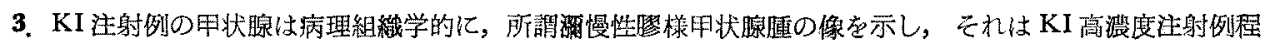
著明であった。

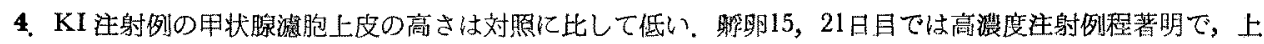

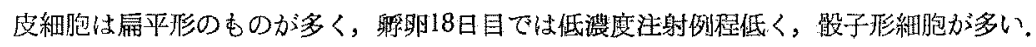

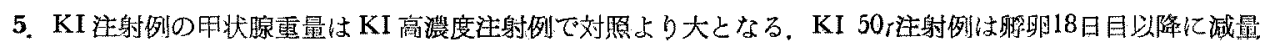
西した。

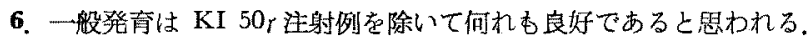

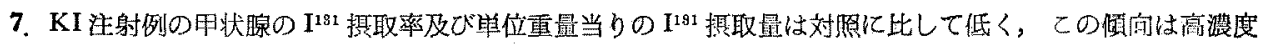
注射例程著明である。

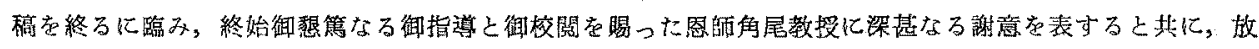
射性沃素使用について程々胙教示を戴いた気热教授に感謝の意を表します。

文献
1) Baumann : Z. physiol. Chem. 21, 319 (1896).
2) Oswald : Münch. Med. Wschr. 74, Nr. 42, 1783 (1927).
3) Kendall : JAMA 64, 2042 (1915).
4) 分担執筆：甲状腺の䠗床 9 (1957) より引用.
5) Plummer, H.S. : JAMA 80, 1955 (1923).
6) 中谷 : 十全会誌 44, 2058 (1939).
7) 竹本：岡山医誌 46,709 (1934).
8) Turner, H.H. et al. : J. clin. Endocrinol. \& Metabol. 16, 141 (1956).
9)堀内：日本医事新埾 No. 1641，88 (1955).
10) 俩田: 日内分必誌 3,1 (1927).
11)大西：同誌 6, 924 (1930).
12）山口：日薬理誌 51，173(1955).
13) 山口 : 同誌 51, 191 (1955).
14) 山田：同誌 51, 298 (1955).
15) 川北 : 同誌 51, 327 (1955).
16) 白須賛：略和医誌 17，56 (1957).
17) 松本, 外: 日薬理誌 53, 2298 (1957); 
18) Fuguson, T.M. et al. : Endocrinol. 60, 28 (1957).

19) Zawadowsky, B. : Endocrinol. 10, 23 (1932).

20) Bliaiss, B. : Physiol. Zool. 20, 67 (1947).

21) 小林：動雑 61，232 (1952).

22) 前田：日内分泌誌 5, 1929 (1929).

23) 藤井：日新医誌 15，16917 (1925).

24) 角尾，外：昭和医誌 14，223 (1954).

25)解尾：同誌 17, 1 (1958).

26) 家亦：日萩理誌 54, 165 (1958),

27) 松本：同䓌 53, 249 (1957).

28) 飯山: 同誌 54, 599 (1958).

29) Dennis, B.F. : Texas Reports of Biol. \& Med. 13, 631 (1955).

30) Ferguson, T.M. et al. : Endocrinol. 60, 13 (1957).

31) Kraicziczek, M.: Z. Zell forsch. 43, 421 (1956),

32) 中村：日病理誌 5, 191 (1916).

33) 中村 : 同誌 8, 312 (1933).

34) Gray, S.H. et al. : Berichte ü. ges. Physiol. u. exp. Pharmakol. 41, 561 (1927) より引用.

35) Anderson, W.A.D. : Pathology 3rd Ed. 979 (1957) 上り引用.

36) 狩野：日組録 4，245 (1952).

37) 内野：内分汼及び実験治燎 6，690 (1955).

38) Catz, B. et al. : J. clin. Endocrinol. 12, 228 (1952).

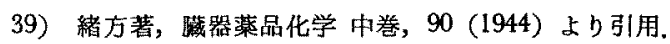

40) Smelser, G.K. : Proc. Soc. Exper. Biol. \& Med. 37, 388 (1937).

41) Meier, J.R. : Endocrinol. 45, 504 (1949).

42) Stanley, M.M. et al. : 同誌 42, 107 (1948).

43) Goldsmith, R.E. et al. : J. clin. Endocrinol. \& Metabol. 16, 130 (1956).

44) 西川：日内分䎵誌 6, 1525 (1930).

45) 岡村著，動物奏験の指針 707 (1941) 上b引用.

46) 䙪川: 綜合踇林 5, 933 (1956).

47) 争尾，外：日内分汹東部誌 2, 2, 10 (1958).

48) 長沼：同誌 2, 1, 9 (1958).

49) Sollmann : A Manual of Pharmacology \& Applications to Therapeutics \& Toxicology 7th Ed. 818 (1948).

50) Kocher：森茂樹著：内分北学（全） 291 (1941) より引用.

51）空地：中外医事新報 1063号, 891 (1938).

52) Hertz, S. et al. : Proc. Soc. Exper. Biol. \& Med. 38, 510 (1938).

53) Hamilion, J.G. : Am. J. Physiol. 127, 557 (1939).

54)鳥銅：綜合踾床 4, 542 (1957).

55) Werner, S.C. et al. : J. clin. Endocrinol. 10, 1054 (1950).

\section{陶錄图铝明}

\section{科胎子甲状腺の肉腿的標本}

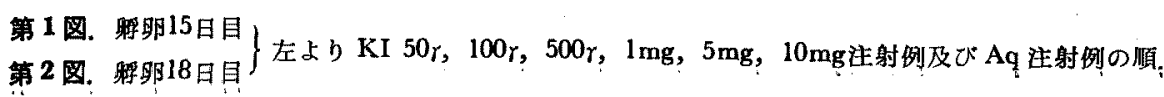


高橋論文附録図（その 1 )

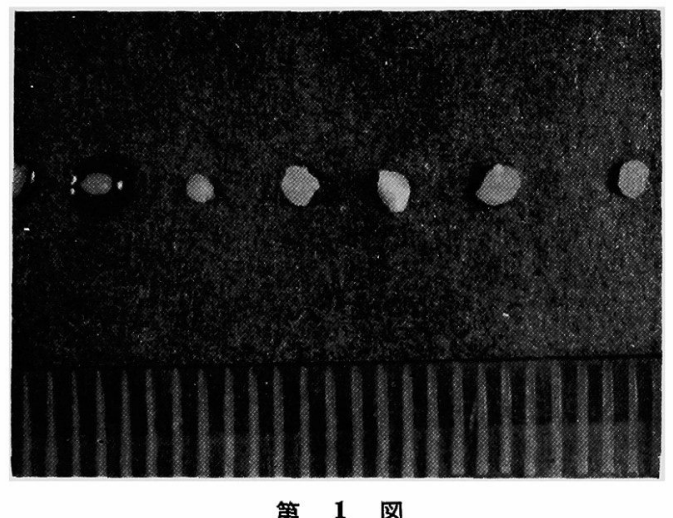

第 1 図

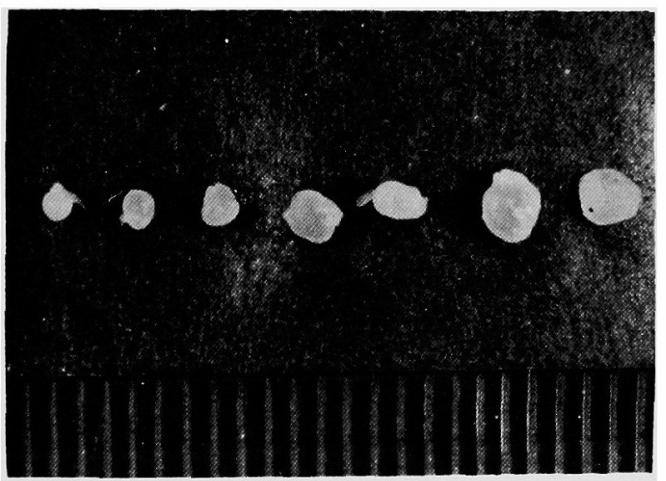

第 2 図

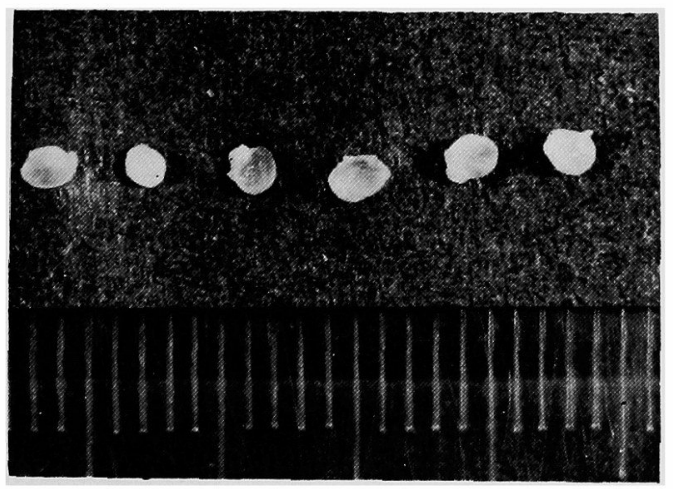

第 3 図 
高橋論文附録図（その 2)

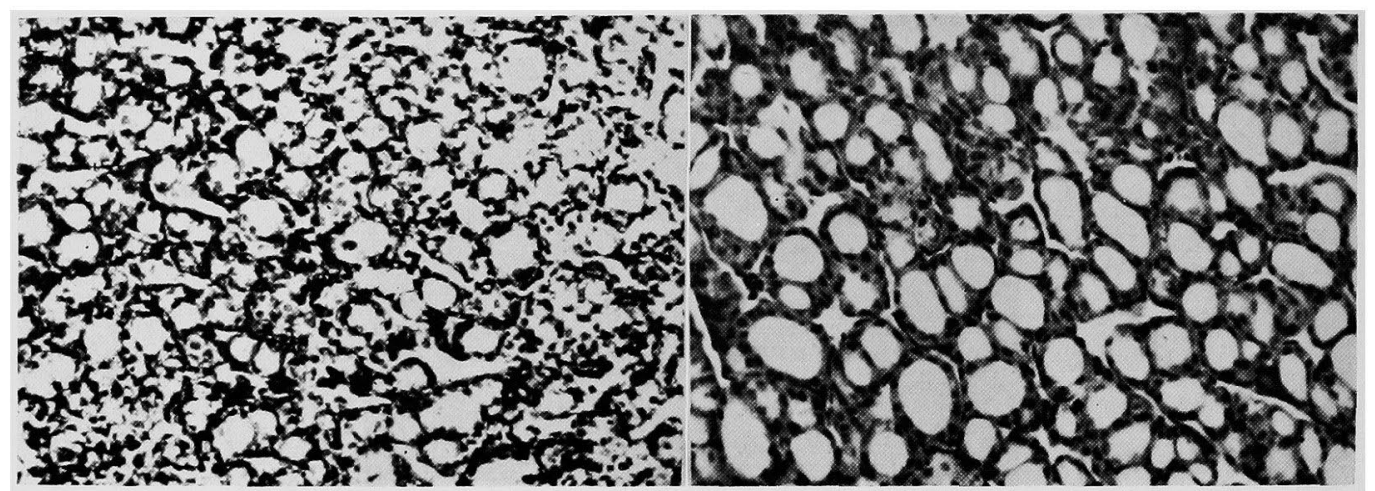

第 4 図

第 7 図

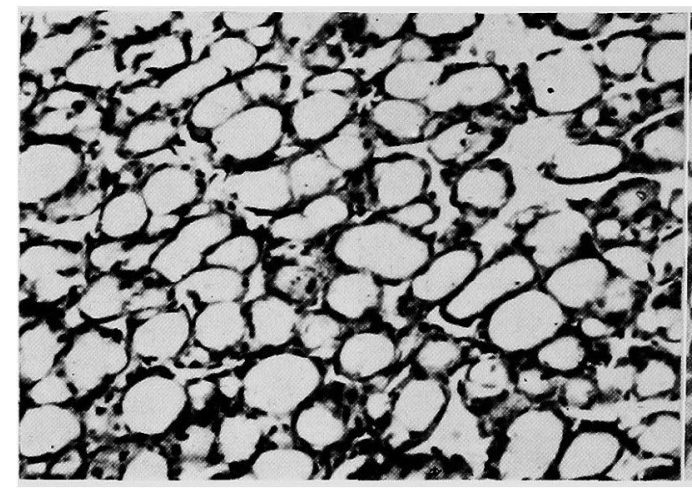

第 5 図

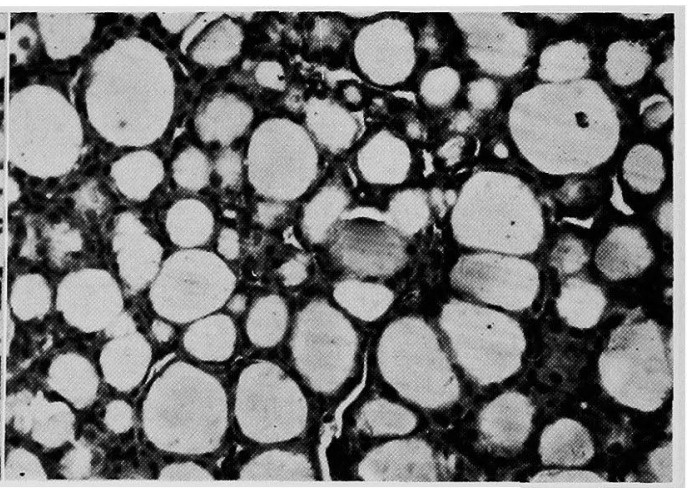

第 8 図

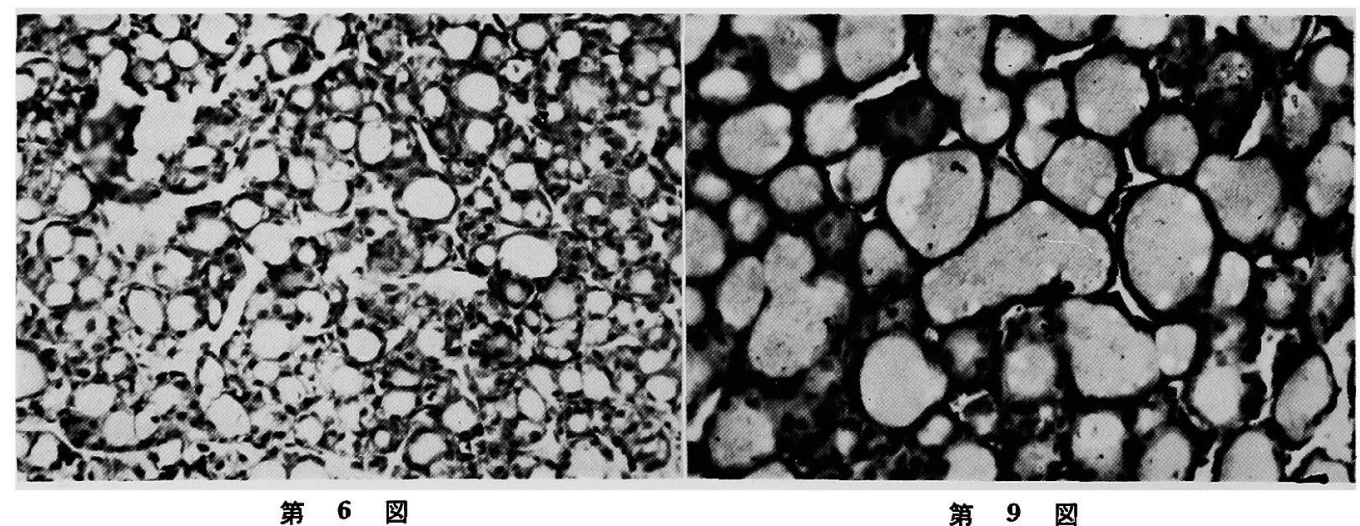


高橋論文附録図（その3）

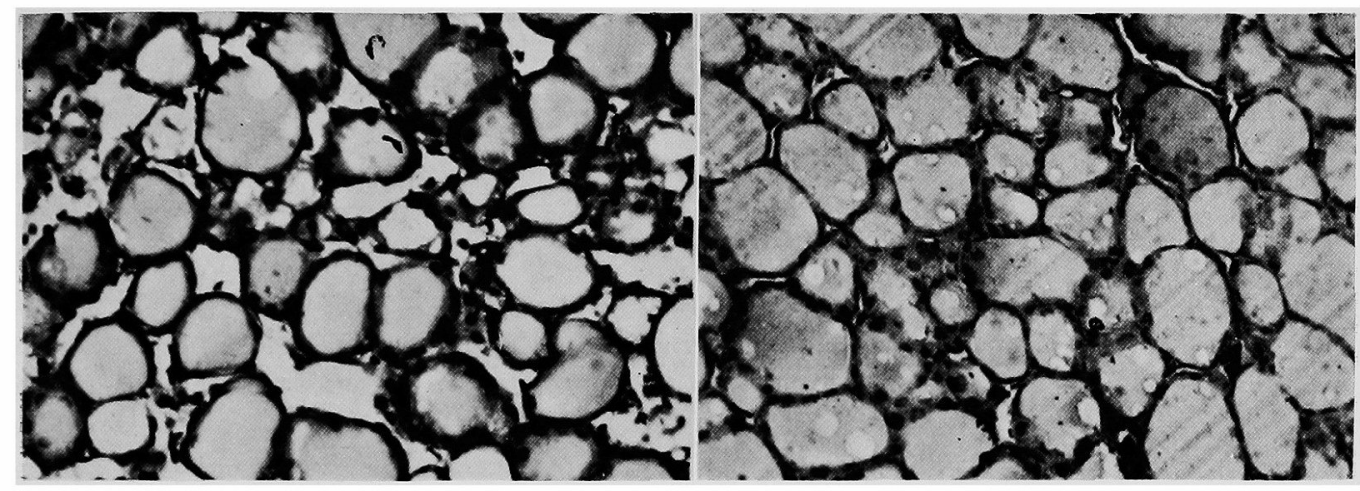

第 10 図

第 13 図

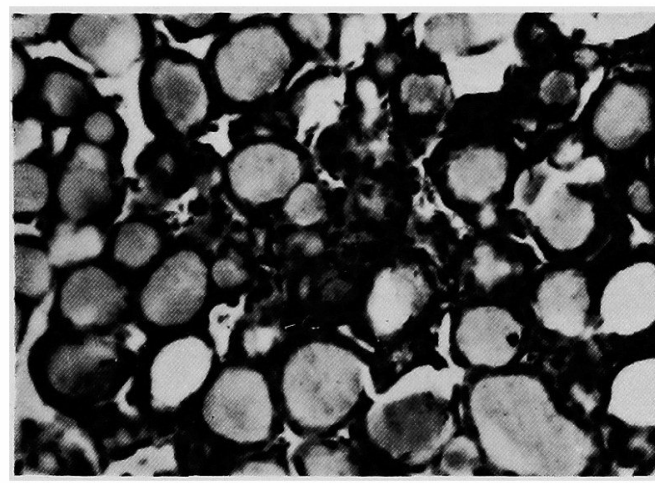

第 11 図

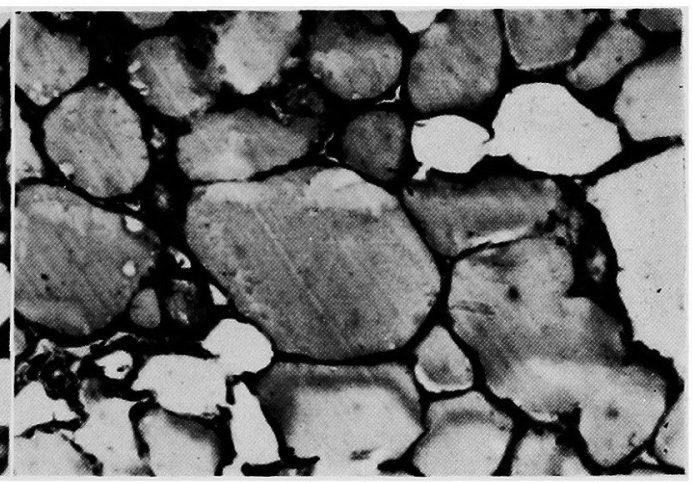

第 14 図

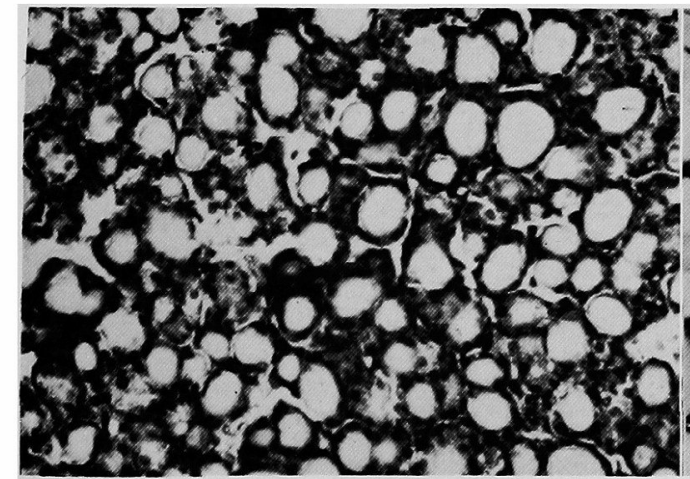

第 12 図

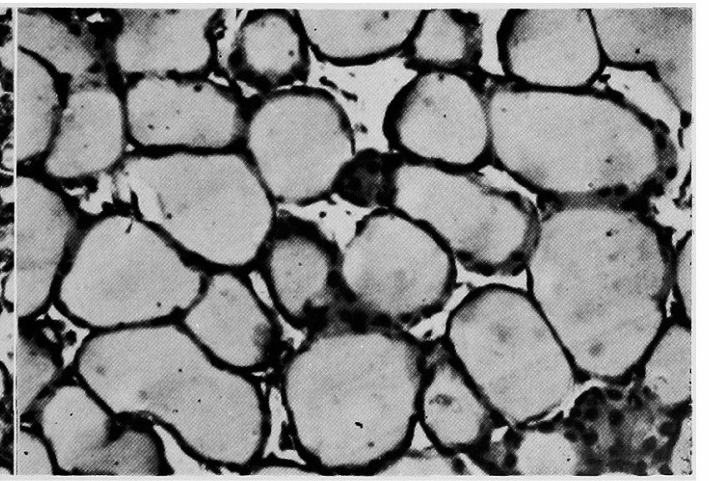

第 15 図 
高橋論文附録図（その 4)

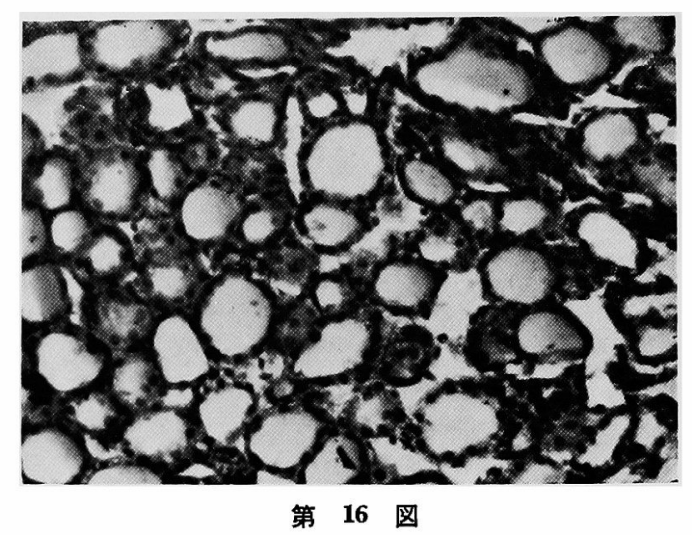




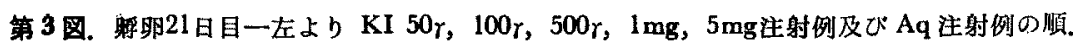

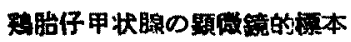

第 4 图. 躬㽢15日目 Aq 注射例。

第 5 図, "KI $5 \mathrm{mg}$ 注射例。

第 6 图. KI 50 r拄射例。

第 7 图. 糡畉18日目 Aq 注射例。

第 8 図. "KI $10 \mathrm{mg}$ 注射例.

第9图. "KI $5 \mathrm{mg}$ 注射例。

第10图。 KI I mg注射例。

第11图. KI 500 r注射例。

第12图。 KI 50r注射例。

第13图。躬率21日目 Aq 注射例。

第14图. "KI $5 \mathrm{mg}$ 注射例.

第15图. $"$ KI l mg注射例。

第16图. KI 50r注射冽. 